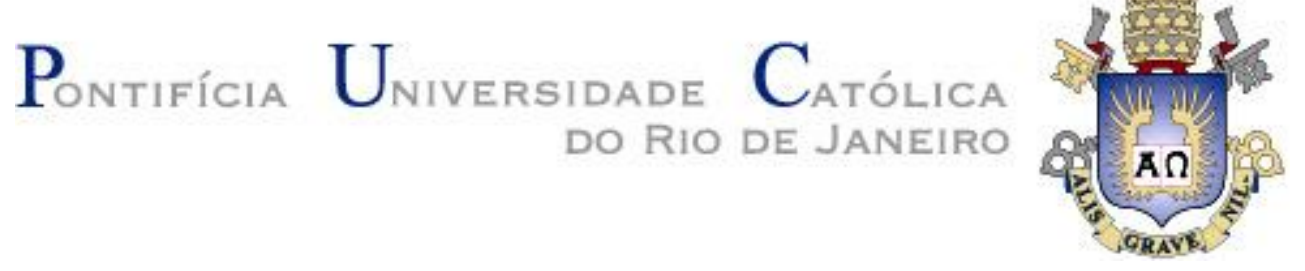

Daniel Martins Abelha

O Impacto das Emoções de um Líder Inautêntico na Percepção de seus Seguidores

Dissertação de Mestrado

Dissertação apresentada ao Programa de Pósgraduação em Administração de Empresas da PUCRio como requisito parcial para obtenção do título de Mestre em Administração de Empresas.

Orientadora: Prof $\stackrel{a}{\text { a }}$ Flávia de Souza Costa Neves Cavazotte

Rio de Janeiro

Abril de 2016 


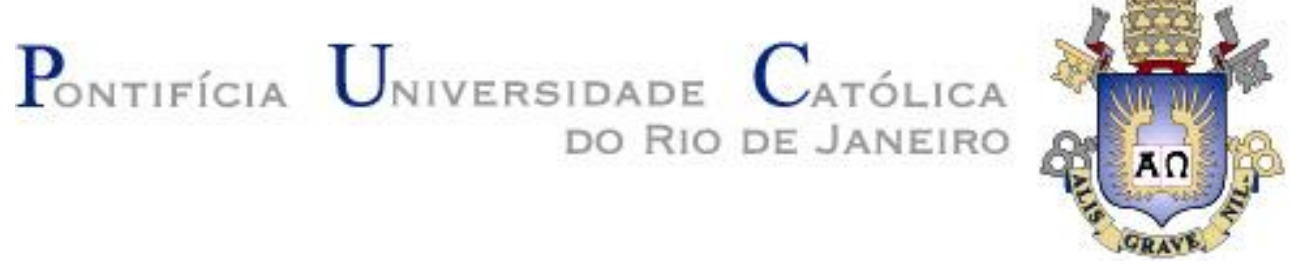

Daniel Martins Abelha

\section{O Impacto das Emoções de um Líder Inautêntico na Percepção de seus Seguidores}

Dissertação apresentada ao Programa de Pósgraduação em Administração de Empresas da PUCRio como requisito parcial para obtenção do título de Mestre em Administração de Empresas. Aprovada pela Comissão Examinadora abaixo assinada.

Profa. Flávia de Souza Costa Neves Cavazotte

Orientadora

Departamento de Administração - IAG/PUC-Rio

Profa. Alessandra de Sá Mello Costa

Departamento de Administração - IAG/PUC-Rio

Prof ${ }^{a}$. Lucia Barbosa de Oliveira Departamento de Administração - IBMEC-RJ

Profa ${ }^{a}$. Mônica Herz Vice-Decana de Pós-Graduação do CCS - PUC-Rio

Rio de Janeiro, 12 de abril de 2016 
Todos os direitos reservados. É proibida a reprodução total ou parcial do trabalho sem autorização da universidade, do autor e do orientador.

\section{Daniel Martins Abelha}

Graduou-se em Administração de Empresas com ênfase em Administração Pública pela Universidade Federal Rural do Rio de Janeiro (UFRRJ) em 2012. Pesquisador e professor nas áreas de Comportamento Organizacional, Gestão de Pessoas e Liderança.

Ficha Catalográfica

Abelha, Daniel Martins

O impacto das emoções de um líder inautêntico na percepção de seus seguidores / Daniel Martins Abelha; orientadora: Flávia de Souza Costa Neves Cavazotte. - 2016.

66 f.: il. (color.); $30 \mathrm{~cm}$

Dissertação (mestrado) - Pontifícia Universidade Católica do Rio de Janeiro, Departamento de Administração, 2016.

Inclui bibliografia

1. Administração - Teses. 2. Emoções. 3. Identificação pessoal. 4. Julgamento ético. 5. Liderança. 6. Percepção de eficácia. I. Cavazotte, Flávia de Souza Costa Neves. II. Pontifícia Universidade Católica do Rio de Janeiro. Departamento de Administração. III. Título. 


\section{Agradecimentos}

À Deus, por iluminar diariamente os meus caminhos e me conceder saúde para seguir em frente.

À minha família, em especial, a minha mãe, Laura Abelha, fonte de inspiração e que dedicou parte de sua vida me ensinando o valor da educação e do caráter.

À minha companheira, Natalie Dantas, por compartilhar os momentos mais importantes da vida e estar sempre ao meu lado.

Aos primos, Alessandra e Alvinho, por me acolherem de forma tão carinhosa. Felizes aqueles que têm a oportunidade de conviver com pessoas tão especiais como vocês.

Aos grandes amigos de infância, em especial, Damian Schelling, Eduardo Juannes, Gabriel Prata, Guilherme Jacinto, Rodrigo Porto, Rômulo Maia, Vinício Salvarezza, Vinícius Jacinto, Vinícius Loureiro e Vitor Moreira. Obrigado pela amizade verdadeira e por estarem presentes em momentos únicos.

Aos colegas do Ramatis, pela forma altruística com que enxergam a vida e por me contagiarem com boas energias.

À minha querida orientadora, Flávia Cavazotte, pela orientação, solidariedade e pela relação de empatia construída ao longo desses dois anos transformando um simples vínculo profissional em um sincero laço de amizade. Obrigado por tudo.

Ao amigo e professor Silvestre Prado, pela generosidade e por ter sido o primeiro a acreditar no meu potencial acadêmico. Muitos de seus valores estão presentes neste trabalho e na forma como enxergo e atuo na academia.

Aos colegas do CEDERJ, pelo ambiente de trabalho amistoso e pela colaboração essencial a coleta de dados dessa pesquisa. 
Aos professores do IAG/PUC-Rio, em especial, as professoras Alessandra Mello, Ana Heloísa e Patricia Tomei, pelos momentos ricos de aprendizagem. Foi um prazer, mesmo que em tão pouco tempo, poder compartilhar ideias e conhecimentos com vocês.

Aos colegas de turma do IAG/PUC-Rio, pela amizade construída e pela troca de experiências pessoais e profissionais.

Aos colaboradores do IAG/PUC-Rio, em especial, a Teresa Campos, ao pessoal da Informática e Apoio, sempre atenciosos as necessidades dos estudantes e que de forma cuidadosa, zelam pelo ambiente aconchegante do IAG.

Ao IAG /PUC-Rio, em geral, pela oportunidade concedida e por ter depositado confiança em mim enquanto mestrando acadêmico e seu representante em congressos e periódicos científicos.

À PUC-Rio, em geral, pela excelente infraestrutura oferecida aos professores e estudantes e, em especial, a Biblioteca Central e seus simpáticos colaboradores.

À CAPES, pelo auxílio financeiro e por investir continuamente nos mais variados estudantes de mestrado e doutorado espalhados pelo Brasil.

E a todos que contribuíram de forma direta ou indireta para a realização deste trabalho, o meu MUITO OBRIGADO! 


\section{Resumo}

Abelha, Daniel Martins; Cavazotte, Flávia de Souza Costa Neves. O Impacto das Emoções de um Líder Inautêntico na Percepção de seus Seguidores. Rio de Janeiro, 2016. 66p. Dissertação de Mestrado Departamento de Administração, Pontifícia Universidade Católica do Rio de Janeiro.

O presente estudo tem o objetivo de investigar se a expressão de emoções positivas (alegria/ânimo), negativas passivas (tristeza/desânimo) e negativas agressivas (raiva) em um líder inautêntico podem afetar a percepção de eficácia, o julgamento ético e a identificação pessoal de seus seguidores quando eles se atentam a um discurso antiético proferido por esse líder. Através da metodologia de experimento, buscou-se analisar como o efeito da expressão emocional deste líder tóxico afeta os julgamentos que seus liderados teriam sobre ele. $\mathrm{O}$ estudo foi realizado em uma amostra de 275 alunos do curso de graduação em Administração de Empresas de uma universidade do Rio de Janeiro. Os resultados confirmaram que líderes inautênticos que expressam emoções positivas são julgados de maneira mais favorável por seus seguidores quanto a sua eficácia e provocam maior identificação pessoal com eles do que aqueles que expressam emoções negativas. A expressão de emoções positivas e de emoções negativas passivas provocaram avaliações mais favoráveis entre os seguidores quanto à conduta ética desses líderes comparativamente à expressão de emoções negativas agressivas.

\section{Palavras-chave}

Emoções; Identificação pessoal; Julgamento ético; Liderança; Percepção de eficácia. 


\section{Abstract}

Abelha, Daniel Martins; Cavazotte, Flávia de Souza Costa Neves (Advisor). The Impact of an Inauthentic Leader's Emotions in the Perception of his Followers. Rio de Janeiro, 2016. 66p. MSc. Dissertation Departamento de Administração, Pontifícia Universidade Católica do Rio de Janeiro.

The present study aims to investigate how positive (happiness) and negative (sadness and aggression) emotions from an inauthentic leader could affect followers' efficacy perception, ethical judgment and personal identification when they note an unethical speech given by this professional. Thus, by experiment methodology, it sought to analyse how the effect of emotional expressions of this toxic leader could influence the evaluation that his team would have on him in contemporary organizations. Through a sample collected from 275 business administration undergraduates, the results confirmed that inauthentic leaders who express positive emotions received better evaluations of his followers as their efficacy perception and personal identification of those who manifest negative emotions. Finally, both positive and passive negative emotions (sadness) expressed by these leaders received more favourable ethical judgments of the followers in relation to aggressive negative emotions.

\section{Keywords}

Efficacy perception; Emotions; Ethical judgment; Leadership; Personal identification. 


\section{Sumário}

1. Introdução.......................................................................... 13

1.1 Contextualização do Problema...................................................13

1.2 Objetivo Principal e Delimitação do Estudo..................................14

1.3 Relevância do Estudo...............................................................15

1.4 Estrutura da Pesquisa.................................................................16

2. Referencial Teórico................................................................17

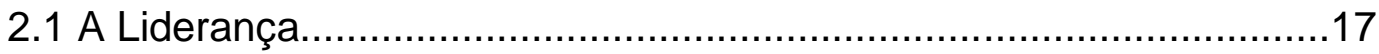

2.2 A Lideranca baseada em Princípios Morais......................................18

2.2.1 A Liderança Ética................................................................20

2.2.2 A Liderança Servidora...................................................21

2.2.3 A Liderança Autêntica...........................................................22

2.2.4 A Liderança Imoral..........................................................24

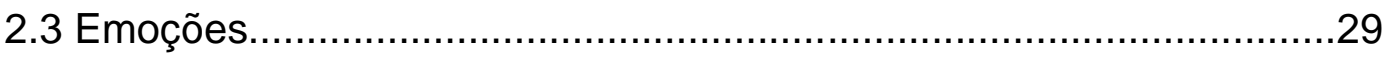

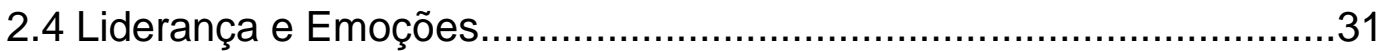

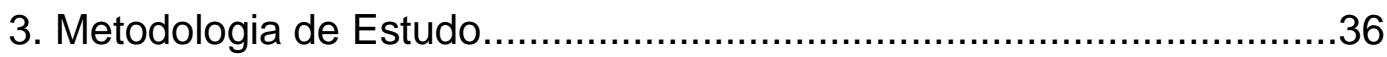

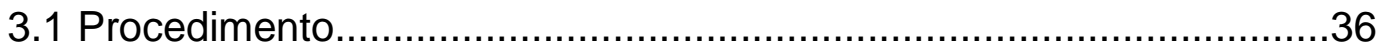

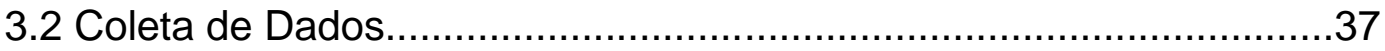

3.3 Escalas de Mensuração.....................................................38

3.4 Amostra............................................................................... 40

4. Análise dos Resultados...............................................................41

4.1 Desenvolvimento Moral dos Entrevistados...................................41

4.2 Efeito da Manipulação das Expressões Emocionais.........................41

4.3 Construtos e as Expressões Emocionais.......................................45

4.4 Discussões do Experimento...................................................49

5 Conclusão e Considerações Finais................................................50 
6 Referências Bibliográficas.

Apêndice 1 - Discurso do Líder nos Vídeos............................................59

Apêndice 2 - Manipulação das Emoções do Líder nos Vídeos..................60

Apêndice 3 - Questionário do Experimento.............................................62 


\section{Lista de Figuras}

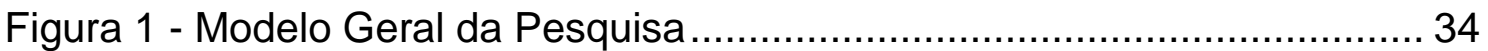

Figura 2 - Comparação (Médias) - Efeito da Manipulação (Positiva) ............... 43

Figura 3 - Comparação (Médias) - Efeito da Manipulação (Agressiva) ............ 43

Figura 4 - Comparação (Médias) - Efeito da Manipulação (Passiva) ................ 44

Figura 5 - Comparação (Médias) - Percepção de Eficácia............................... 46

Figura 6 - Comparação (Médias) - Identificação Pessoal................................. 47

Figura 7 - Comparação (Médias) - Julgamento Ético ...................................... 48 


\section{Lista de Quadros}

Quadro 1 - Estudos sobre Má Liderança nos últimos anos .......................... 27

Quadro 2 - Estatística Demográfica por Vídeo .......................................... 40

Quadro 3 - ANOVA - Desenvolvimento Moral dos Entrevistados.................... 41

Quadro 4 - Efeito da Manipulação (Afetividade Positiva) ............................... 42

Quadro 5 - Efeito da Manipulação (Afetividade Negativa Agressiva) .............. 43

Quadro 6 - Efeito da Manipulação (Afetividade Negativa Passiva) ................. 44

Quadro 7 - ANOVA - Percepção de Eficácia ............................................. 45

Quadro 8 - ANOVA - Identificação Pessoal ............................................. 46

Quadro 9 - ANOVA - Julgamento Ético ................................................ 47

Quadro 10 - ANOVA - Emoções Negativas ................................................. 48 
Se suas ações inspiram os outros a sonhar mais, aprender mais, fazer mais e ser mais, você é um líder.

John Quincy Adams

Parto da premissa que a função da liderança é produzir mais líderes, não mais seguidores.

Ralph Nader 


\section{1 \\ Introdução}

1.1

Contextualização do Problema

A liderança é um fenômeno social que está presente em todas as coletividades humanas. Quando duas ou mais pessoas interagem entre si, elementos do processo de liderança podem surgir, com o líder influenciando, persuadindo, orientando ou servindo de modelo comportamental para o seu grupo. As ações dos líderes impactam todos os setores da sociedade, desde as relações familiares até as instituições públicas e privadas (DAY \& ANTONAKIS, 2012).

Líderes ocupam espaços desde os primórdios da humanidade modificando o seu ambiente, conduzindo pessoas a perseguirem objetivos predeterminados e, muitas das vezes, regulando o convívio social. Foi assim com grandes personalidades históricas, como Aristóteles em seu livro "Retórica" cujas reflexões se pautavam no poder de persuasão dos líderes da época, por grandes reis e generais militares e, na contemporaneidade, com líderes de grandes corporações e instituições governamentais (ANTONAKIS, 2012).

Os estudos científicos sobre a liderança têm buscado identificar o que levaria à eficácia de um líder, independentemente do setor ou área profissional em que atue. Estudos preliminares demonstraram que líderes de sucesso eram aqueles que obtinham êxito conduzindo seus liderados a alcançarem metas predeterminadas pela organização, sem necessariamente considerar as expectativas dos envolvidos no processo (BRYMAN, 2004). Com o passar do tempo, o conceito da liderança ampliou-se e passou a agregar não só as dimensões técnicas desse profissional, como também a relação comportamental, emocional e ética perante seu público alvo (ASHAKANASY \& HUMPHREY, 2011).

Este tema tem sido particularmente importante nos dias de hoje, onde se tem visto no mundo dos negócios organizações até então sólidas enfrentarem crises e decretarem falência devido à má conduta de suas principais lideranças, cujos comportamentos moralmente questionáveis deram margem ao surgimento de inconvenientes organizacionais, como escândalos financeiros, corrupção, perdas mercadológicas decorrentes da má reputação institucional, clima e cultura 
organizacionais ruins entre trabalhadores e, em última instância, perecimento da saúde organizacional (GARDNER, 1995).

Muitos destes líderes têm as competências técnicas necessárias aos cargos que ocupam, porém, falham em habilidades interpessoais e morais, apresentando dificuldades para se relacionar de forma transparente com seus seguidores e para tomar decisões éticas. Além disto, destacam-se os inúmeros casos dos que se apoderam intencionalmente do uso das emoções e de imponentes discursos a fim de manipular seguidores e maximizar interesses individuais (RAJAH et al, 2011). Estes líderes podem ser considerados tóxicos e inautênticos devido aos malefícios que trazem para as pessoas e para o âmbito institucional ao seu redor.

Profissionais desta categoria surgem como desagregadores de culturas participativas e tornam-se uma ameaça real à boa liderança organizacional. Promovem agressões verbais e comportamentais aos seus seguidores que, afetados por esse desvio de conduta, abalam-se psicologicamente. Porém, muitas vezes esses líderes conseguem conquistar seu grupo de interesse seduzindo-os e convencendo-os através de sua manipulação emocional. Assim, o presente trabalho buscou investigar este tipo de indivíduo que exerce a má liderança nas organizações, a fim de verificar se a percepção de seus observadores sobre ele varia em função de sua expressão emocional, apesar de proferir um discurso recheado de inautenticidade e princípios antiéticos.

\section{2}

\section{Objetivo principal e Delimitação do Estudo}

O objetivo do estudo foi investigar através de um experimento como a expressão emocional de um líder inautêntico poderia influenciar o julgamento de seus liderados sobre ele em organizações contemporâneas. De forma específica, o trabalho buscou explorar se a expressão de emoções positivas (alegria) e negativas (tristeza e raiva) deste líder tóxico afeta a percepção de eficácia, o julgamento ético e a identificação pessoal de seus seguidores com ele quando atentam a um discurso antiético proferido por esse profissional.

Quanto à delimitação do estudo, destaca-se a de se aprofundar na temática da má liderança, integrando as dimensões comportamentais da ética e emoções de um líder. Assim, buscou-se investigar líderes que apresentam um discurso inautêntico, sendo entendidos neste trabalho como todos aqueles que endossam a 
falta de transparência, moralidade, autoconsciência e processamento balanceado de informações na empresa (WALUMBWA et al, 2008), e a percepção de seus observadores em função do uso de emoções na comunicação.

Vale ressaltar que o experimento considerou apenas os estados emocionais da alegria, tristeza e raiva. Assim, qualquer outro tipo de emoção que não seja uma dessas três, não foi considerado nessa pesquisa. Além disto, não é o foco deste estudo se aprofundar conceitualmente em outras dimensões comportamentais que não envolvam a conduta ética e emocional de um líder, tendo este trabalho se reservado a comentá-las brevemente no referencial teórico.

\section{3}

\section{Relevância do Estudo}

O estudo das emoções melhora a compreensão do comportamento no ambiente de trabalho, e tem despertado o interesse nas pesquisas sobre seu papel como ferramentas de contágio social, de influência sobre a percepção humana e, em casos específicos, de manipulação de pessoas (ASHAKANASY \& HUMPHREY, 2011). E isto é particularmente interessante quando se analisa a interferência de líderes inautênticos não apenas em ambientes de negócio, mas também no meio sociopolítico, algo tão presente na sociedade brasileira atual, na qual indivíduos frequentemente agem de maneira manipuladora para obterem vantagens pessoais em detrimento de benefícios sociais.

Este trabalho torna-se relevante ao analisar se as pessoas podem ser mais ou menos influenciadas por indivíduos que apresentam posturas e defendem princípios associados à má liderança em função do tom emocional de seus discursos. Notoriamente, maus líderes parecem dominar a arte de manipular opiniões e julgamentos pessoais através do uso intenso de discursos teatralizados, recheados de conotações emocionais e expressados por linguagens corporais e faciais apropriadas aos seus interesses (RAJAH et al, 2011). Alguns dos casos interessantes a serem notados são o de líderes políticos como Adolf Hitler ou Mao Tsé-Tung, e outros tantos presentes em ambientes empresariais que, apesar de não se mostrarem tão evidentes nos canais midiáticos, colaboram intensamente com um ambiente de corrupção e perecimento organizacional.

Além disto, a maioria dos estudos que relacionam o uso das emoções à prática da liderança enfatiza os aspectos positivos das emoções, procurando 
entender a sua relevância para o desenvolvimento de líderes de sucesso (BONO \& ILIES, 2006). Desta forma, ainda são incipientes, em âmbito acadêmico, estudos que busquem compreender o impacto negativo que a expressão de emoções pode gerar em ambientes profissionais, bem como a maneira como líderes se comportam frente a seus seguidores, utilizando-se das emoções para darem credibilidade a práticas desonestas (EINARSEN et al, 2007).

Do ponto de vista do contexto nacional, maior ainda será a relevância deste estudo, já que o trabalho colabora com o avanço das pesquisas sobre má liderança no Brasil, tema ainda escasso quando se busca pesquisá-lo em sistemas que indexam a produção científica brasileira na área de Administração, como o SPELL (Scientific Periodicals Electronic Library) ou o Portal de Periódicos da CAPES. Ademais, colabora com o estudo da liderança de uma forma ampla, assunto este que apesar de ser propagandeado no universo de consultoria e coaching, tem sido pouco explorado através de estudos científicos pela academia brasileira.

\section{4}

\section{Estrutura da Pesquisa}

O trabalho se divide em três partes, sendo a primeira a revisão da literatura na área abordando conceitos gerais sobre liderança, sua relação com princípios morais, as principais correntes teóricas nesse campo (liderança ética, servidora e autêntica) e a liderança imoral ou tóxica. Logo após, é feita uma investigação conceitual sobre as emoções e suas diferentes dimensões e, por fim, relaciona-se a questão das emoções com o estudo de características imorais, como a inautenticidade no processo da liderança. A seção apresenta o modelo geral da pesquisa e a formulação das hipóteses.

$\mathrm{Na}$ segunda parte encontram-se os procedimentos metodológicos utilizados no experimento, com detalhamento da coleta de dados, escalas de mensuração, informações estatísticas como população, amostra, demografia dos dados, interpretação dos resultados através da análise da variância (ANOVA) e teste Tukey $H S D$, e discussões a respeito dos testes de hipóteses e a relação de seus resultados com a literatura existente.

$\mathrm{Na}$ terceira parte está a conclusão e as considerações finais do trabalho, implicações práticas na área da liderança organizacional, limitações do estudo e propostas de novas pesquisas a fim de se ampliar o conhecimento da área. 


\section{2}

\section{Referencial Teórico}

2.1 .

A Liderança

$\mathrm{Na}$ ciência social aplicada, diversos estudos foram realizados com o intuito de se compreender melhor o fenômeno da liderança. Desde tempos remotos, quando modelos organizacionais ainda eram precários, o fenômeno da liderança já estava presente na sociedade, seja para conduzir pessoas em proveito de determinada atividade, ou para enfrentar algum desafio de adaptabilidade social (MARKHAM, 2012). Entretanto, um profundo entendimento acerca da sua essência continua sendo um desafio para a humanidade, sendo a liderança um dos temas mais pesquisados, mas que menos se tem conhecimento na área de comportamento organizacional (DAY \& ANTONAKIS, 2012).

A liderança pode ser compreendida sobre inúmeros ângulos. Dentre alguns, destaca-se a sua dinâmica vista como um processo que envolve a razão e a emoção humana, no qual o líder eficaz seria aquele que teria a sensibilidade de julgar o momento ideal para se tomar ações baseadas na tecnicidade, ou pôr em prática competências socioemocionais em busca de uma melhor convivência frente seus seguidores (NORTHOUSE, 2013). Desta forma, a liderança está intimamente ligada à ciência, fazendo-se uso de suas ferramentas racionais, bem como com a arte, compreendendo de forma profunda as relações humanas e suas manifestações emocionais (HUGHES, et al, 2005).

Quando se analisa a literatura sobre o desenvolvimento do líder eficaz, diversos foram os estudiosos que procuraram compreender os fatores que impactavam na melhoria de seu desempenho e a relação que tinham com seus seguidores (CAVAZOTTE et al, 2013; KELLEY, 1988; KOTTER, 2001). De uma forma geral, pode-se afirmar que o seu sucesso é fruto de duas grandes competências pessoais. De um lado, a sua habilidade intrapessoal e características decorrentes, como o autoconhecimento, inteligência emocional e cognitiva, experiência e certos traços de personalidade, e por outro, suas habilidades interpessoais, como a capacidade de orientar seus liderados em momentos de mudança, a habilidade em se comunicar empaticamente e expressar emoções 
adequadas em momentos adversos, e a competência para inspirar seus pares profissionais através de uma postura transparente e ética (DAY et al, 2014).

A busca por estas qualidades pessoais e interpessoais passa pelo discernimento que o líder adquire em relação a si mesmo, pois todo líder que tem consciência e humildade suficiente, percebe que é limitado e necessita dos seus seguidores para ampliar suas competências (AVOLIO et al, 2004). Ademais, precisa ter em mente que seus seguidores possuem valores, motivações e expectativas diferentes que devem ser levadas em consideração para a potencialização de seu poder de influência (AVOLIO \& BASS, 2004).

Além disto, o contexto em que este profissional atua necessitaria de certa atenção, isto porque um dos pilares fundamentais da liderança seria a capacidade desse líder mapear o ambiente onde se encontra, perseguindo oportunidades e minimizando ameaças, adaptando-se a um universo marcado por incertezas e mudanças (STENMARK \& MUMFORD, 2011).

Tendo isto em vista, percebe-se que a linha que separa a boa liderança da má liderança está na análise de seus aspectos técnicos, socioemocionais e morais, isto é, até que ponto esse líder consegue demonstrar competências conceituais inerentes aos seus papéis estratégicos, apresentar maestria na habilidade de se comunicar e compreender o próximo, e expressar virtudes morais que promovam o bem comum (KELLERMAN, 2004).

\section{2}

\section{A Liderança baseada em Princípios Morais}

Durante décadas, a sociedade presenciou líderes que exerciam sua influência sem necessariamente se importarem com as consequências de seus atos, disfarçados por uma personalidade entusiástica, capazes de conquistar ouvintes por meio de discursos carismáticos e recheados de conotações emocionais (ANTONAKIS, 2012). Através de uma postura maquiavélica, estes profissionais se utilizavam dessas habilidades sociais a fim de persuadirem seus liderados e dominarem territórios organizacionais (DELUGA, 2001).

Apesar do carisma ser um instrumento que beneficia a liderança, as pessoas começaram a perceber que ele, por si só, não levava a uma liderança eficaz em longo prazo, isto porque notaram que líderes carismáticos não necessariamente baseavam suas decisões em valores éticos (CIULLA, 2004). 
Logo, uma liderança baseada em princípios morais, passou a ser demandada pela sociedade que cada vez mais tem sido intolerante com profissionais que possuem uma visão tacanha de seu cerco organizacional e demonstram uma preocupação superficial perante seus stakeholders (KIRKPATRICK, 2011). De maneira consciente, buscam expor uma falsa imagem de profissional responsável, mas quando desmascarados, perdem sua confiança e reputação profissional (ANDERSSON \& BATEMAN, 1997).

Esta nova tendência em se preocupar com a integridade do líder, tem sido vista em outros campos de pesquisa referentes às novas abordagens da liderança, como é o caso do líder transformador, base conceitual para o desenvolvimento de líderes transformacionais, sendo ele o indivíduo que age com alto grau de moralidade perante seus seguidores, respeita seus valores e se compromete profundamente com suas necessidades (BURNS, 1978).

A liderança baseada em princípios morais surge como um canal aberto que possibilita a troca de capital social e intelectual entre líder e liderados, processo esse fundamental para o fortalecimento de laços e prevenção de comportamentos antiéticos no cotidiano laboral (CIULLA, 2004). Estas relações estão presentes no ambiente organizacional, cujos líderes seriam os responsáveis por mediar metas empresariais e expectativas sociais. Assim, através de uma percepção justa, buscariam maximizar benefícios mútuos e estimular o engajamento de seus seguidores em direção a objetivos coletivistas (FREITAS, 1994).

Entretanto, muitos desses líderes, anestesiados pelo poder que possuem, desviam-se do foco de guiar pessoas em prol de objetivos compartilhados para a satisfação de interesses voltados ao ego pessoal (VIEIRA \& LACERDA, 2010). Com uma postura arbitrária, passam a comandar ao invés de liderar, negligenciam o bem comum e, muitas das vezes, manipulam a fim de encobrirem determinadas falhas de caráter e condutas antiéticas (NASEER et al, 2015).

Ao analisar a literatura acerca da liderança baseada em princípios morais, percebe-se a presença de estudos que procuraram compreender o impacto que o caráter ou a sua ausência tiveram para a eficácia de um líder, seja através da sua presença fomentando um clima de cooperação e confiança entre líder e seguidores, seja pela sua ausência, propiciando o surgimento de ambientes de manipulação e insegurança entre seus participantes (CIANCI et al, 2014; CIULLA, 2004; GREENLEAF, 2002; KELLERMAN, 2004). Apesar de muitas 
pesquisas baseadas nestes princípios se complementarem e, em outros casos, se confundirem pelo seu nível de similaridade, elas podem ser classificadas em três vertentes, presentes na literatura: a liderança ética, servidora e autêntica.

\subsection{1}

\section{A Liderança Ética}

A definição de ética origina-se dos primórdios da era platônica, cujo termo deriva da palavra grega "ethos", que significa "conduta" ou "caráter" (NORTHOUSE, 2013). Seu conceito passa pelo entendimento da moral, que seria o conjunto de regras de determinado grupo social, desenvolvido ao longo de anos através de suas práticas e costumes culturais. Já a ética, componente essencial também das lideranças autêntica e servidora, busca a reflexão sobre a moral julgando quais seriam as melhores atitudes a serem tomadas em termos de maximização do bem comum desse grupo social (SROUR, 2003).

Assim, o líder ético surge como o indivíduo que está sempre atento à correção de seus atos e suas consequências para o bem-estar de seus seguidores, expressando um comportamento altruísta, carregado de emoções empáticas e virtudes pessoais condizentes com seu caráter (SROUR, 2003). Dentre alguns de seus valores, destacam-se a sua preocupação em criar um ambiente de união e honestidade entre os envolvidos, a coragem em seguir orientações voltadas a maximização de benefícios gerais e não de privilégios pessoais, o uso de sua influência para motivar trabalhadores a se expressarem de forma sincera, além de fornecerem suporte emocional ao desenvolvimento pessoal e profissional de seus seguidores (HANNAH \& AVOLIO, 2011).

Existem traços de personalidade que podem facilitar o surgimento destes tipos de líderes, mesmo quando expostos a adversidades. Dentre algumas destas características psicológicas, destacam-se o seu discernimento moral frente dilemas éticos, a resiliência emocional em momentos de turbulência organizacional e o equilíbrio pessoal com que lidam com problemas nesses momentos, sendo fiéis aos seus princípios que irão norteá-los e guiar seus seguidores em direção a superação desses desafios (LUTHANS \& AVOLIO, 2003).

A ética surge como elemento crucial para que se instale um espaço de confiança nas relações sociais e organizacionais. Em um estudo interessante de Sobral (2010), o autor concluiu que negociações éticas estimulam uma postura de 
confiança interpessoal e fortalecem laços de parceria. Caso contrário, isto é, quando há uma postura competitiva de um dos atores envolvidos no processo negocial, menos colaborativo este será em prol do bem-comum e maior também serão as chances desse indivíduo tolerar comportamentos desonestos quando exposto por questões que envolvam dilemas éticos (SOBRAL, 2010).

Assim, surge a necessidade destes líderes manterem-se íntegros em suas atuações profissionais, já que seus seguidores estarão sempre atentos as suas ações e, caso pratiquem desvios de conduta, irão perder a confiança necessária desses trabalhadores. Logo, quando os valores defendidos por um líder não se ajustam com suas ações, este profissional terá seu poder de atuação reduzido por esses liderados que deixarão de segui-lo e desconfiarão de sua conduta com frequência (CIULLA, 2004).

\section{2 .2}

\section{A Liderança Servidora}

Ao longo de anos, costumava-se pensar que a liderança estava resumida ao processo de conduzir trabalhadores a atingirem metas institucionais, sem necessariamente se preocupar com as necessidades reais desses indivíduos (DAY et al, 2014). Com o desenvolvimento de abordagens contemporâneas da liderança e de um nível maior de consciência das pessoas, as atribuições desse profissional tornaram-se mais abstratas, sendo ele considerado nos dias de hoje, um inspirador de valores e modelo de conduta para seus seguidores (BRYMAN, 2004).

A liderança servidora, em evolução simultânea com esta nova mentalidade, surge em meio a sociedade atual, degradada pela ganância e consumismo desenfreado (GREENLEAF, 2002). Líderes servidores transcendem o egocentrismo humano, aguçado pela sociedade materialista, ao nutrirem um sentimento de cumplicidade pelo próximo, doarem-se a causas sociais, combaterem injustiças e renunciarem a prazeres pessoais em defesa da coletividade. São indivíduos que inspiram propósitos profundos nas pessoas e lideram pelo exemplo, servindo o seu próximo e não impondo ordens a ele (BLANCHARD \& HODGES, 2003).

Este envolvimento com os estágios mais profundos do ser humano pode ser verificado por grandes personalidades que percorreram a história, como Madre Teresa de Calcutá, Mahatma Gandhi ou Nelson Mandela. Dotados de princípios 
altruísticos, líderes servidores abnegam de seus próprios interesses em prol de um propósito maior, que busque servir a justiça e ao bem comum (GREENLEAF, 2002). Como alguns de seus valores básicos dizem respeito à integridade que imprimem em seus comportamentos e a confiança que adquirem de seus seguidores, conclui-se que estes indivíduos são avessos a corrupção ou a qualquer prática que venha ferir sua idoneidade (SUN, 2013).

No espaço de trabalho, estes líderes atuam como verdadeiros mentores de seus seguidores, acompanhando o desenvolvimento de suas competências e dando-lhes a autonomia necessária para que possam potencializar seus conhecimentos e habilidades. Ademais, líderes servidores compartilham o poder advindo de sua posição hierárquica na estrutura organizacional e buscam consultar as ideias e opiniões de seus subordinados sobre problemas e desafios que surgem no cotidiano laboral (CHINIARA \& BENTEIN, 2015).

A liderança servidora é mais facilmente vista em ambientes que se alinham com suas características, em instituições que desenvolvem culturas de baixo apego ao poder, espaços para livre expressão e incentivo a liderança participativa (SUN, 2013). Quando bem aceita, ela promove a colaboração entre trabalhadores que, imersos a uma cultura de mútua doação, comprometem-se com seus papéis organizacionais (GREENLEAF, 2002).

\subsection{3}

\section{A Liderança Autêntica}

A liderança autêntica surge como uma demanda da sociedade atual que tem presenciado o aumento de casos de escândalos financeiros provenientes de balanços adulterados, corrupção entre governos ou instituições que não se comprometem em compartilhar a verdade com seu público externo. Esta falta de transparência generalizada tem gerado insegurança nas pessoas, que cada vez mais rogam pela presença de líderes mais honestos, em que elas possam confiar (NEIDER \& SCHRIESHEIM, 2011).

O desenvolvimento do conceito de liderança autêntica importou conhecimentos da área da psicologia comportamental e de estudos sociológicos da ética, aplicados em ambientes de negócio (CIANCI et al, 2014). Ademais, ressalta-se que esse conceito carece ainda de um melhor amadurecimento teórico, 
principalmente em estudos que verifiquem o efeito nocivo que uma liderança inautêntica poderia causar em ambientes organizacionais (AVOLIO et al, 2004).

Diversas são as linhas de pensamento sobre a liderança autêntica. Uma delas diz respeito às características intrapessoais demonstradas por este profissional em seu cotidiano laboral (SHAMIR \& EILAM, 2005). Um estudo interessante foi o de George (2003), cujo trabalho propõe a presença de cinco características básicas, sendo elas a consistência moral com que esses líderes seguem suas convicções internas, a apresentação de um propósito bem delineado em relação aos seus objetivos futuros, a demonstração da paixão pelo que fazem, a autodisciplina e a conexão com seu próximo através do compartilhamento de experiências pessoais e pelo uso de storytelling (GEORGE, 2003).

Uma outra perspectiva, mais aceita e investigada na academia, define a liderança autêntica como um processo que busca enfatizar as qualidades necessárias para o desenvolvimento do líder autêntico e dos seguidores que confiam e dão credibilidade a esse indivíduo (GARDNER et al, 2011). Dentre seus estudos, o mais conhecido é o de Walumbwa et al (2008), que mapeou os atributos responsáveis pelo surgimento da liderança autêntica. Através da criação de seu modelo conceitual, os autores descreveram quatro dimensões que, juntas, promoveriam o desenvolvimento ético, social e profissional dos envolvidos. São elas: a autoconsciência, os princípios morais internalizados, o processamento balanceado e o relacionamento transparente (WALUMBWA et al, 2008).

Pela autoconsciência, entende-se como o discernimento que o líder possui em relação as suas limitações e convicções, e a responsabilidade que tem perante seus seguidores. Princípios morais internalizados é o processo de autocontrole em que o indivíduo não permite que sua conduta seja afetada por pressões externas, mantendo-se fiel aos seus princípios pessoais. Já o processamento balanceado é a prática da escuta ativa demonstrando respeito aos valores e opiniões de seus liderados. Por último, o relacionamento transparente indica a postura humilde com que este líder se comunica com seus seguidores, compartilhando de forma sincera suas crenças e seu modo de pensar (WALUMBWA et al, 2008).

Líderes autênticos demonstram emoções genuínas através do alinhamento de seus valores com seus comportamentos, inspirando confiança e estimulando atitudes éticas em seus liderados (ASHAKANASY \& HUMPHREY, 2011). Quando bem empregada, a liderança autêntica proporcionaria a eficácia em 
equipes de trabalho, primeiro pela capacidade desses líderes em se comunicarem francamente indicando de maneira clara a responsabilidade que cada envolvido terá para o bom funcionamento dos processos organizacionais, e segundo pelo estímulo a um ambiente leal entre seus colaboradores que se sentem pertencentes a algo maior e se engajam nos projetos desenvolvidos pelo líder autêntico (AVOLIO et al, 2004).

As três perspectivas da liderança baseada em princípios morais (ética, servidora e autêntica) discutem a boa liderança orientando-se pela integridade e por valores morais presentes no líder. Além disto, vale ressaltar que a liderança autêntica foi a que mais prosperou e deu frutos na forma de pesquisas, com ampla utilização e investigação acadêmica do modelo conceitual de Walumbwa et al (2008), razão pela qual o presente trabalho se pautou neste modelo em vez de outros presentes na literatura, como o modelo conceitual de Neider \& Schriesheim (2011). Na próxima seção, a discussão se concentrará ainda na dimensão moral da liderança, porém, na investigação de líderes que falham na apresentação desses atributos comportamentais em seus ambientes de trabalho, isto é, líderes inautênticos e antiéticos que colaboram com o desenvolvimento da má liderança e são responsáveis por disseminar toxinas nos ambientes social e organizacional.

\subsection{4 \\ A Liderança Imoral}

Princípios morais parecem ser o elemento comum no desenvolvimento das perspectivas sobre a boa liderança. Assim, presume-se que líderes eficazes dedicam tempo e esforço à manutenção de sua consistência moral. Por estarem em uma posição de alta visibilidade, eles terão seguidores que estarão constantemente lhe avaliando e, caso ajam de maneira eticamente questionável, estarão pondo em risco sua credibilidade (CIULLA, 2004). Pesquisas têm demonstrado que líderes que são julgados como indivíduos antiéticos, são percebidos geralmente como profissionais ineficazes e tendem a estimular um clima de pessimismo entre seus seguidores em relação ao seu futuro profissional (HOOGH \& HARTOG, 2008).

Além disto, líderes que atuam de maneira cínica em seus ambientes de trabalho não só geram a desconfiança entre seus colaboradores, como também os estimulam a agirem de maneira similar a sua, isto porque quando cometem desvios de conduta e não são punidos pela organização, transmitem a mensagem 
que desonestidade e impunidade são aceitáveis naquela instituição. Cria-se, então, um terreno hostil entre a força de trabalho e a própria empresa que, em breve, terá que lidar com o problema de se ter instalado um clima organizacional perigoso a boa convivência de seus trabalhadores (ANDERSSON \& BATEMAN, 1997).

Pesquisas têm demonstrado ainda que líderes imorais, como os inautênticos, apresentam dificuldades em orientar pessoas no ambiente organizacional, isto porque falham na construção de um relacionamento transparente e perdem a confiança necessária entre seus seguidores impossibilitando, assim, a sua atuação como agente catalisador de mudanças e potencializando as chances de seus colaboradores apresentarem níveis menores de comprometimento afetivo e perda de desempenho organizacional (RUBIN et al, 2009; KONING \& KLEEF, 2015). Desta forma, quando há um conflito moral na postura destes líderes que contrarie as expectativas de seus liderados, cria-se um clima de desconfiança entre as relações dificultando a possibilidade de entrosamento entre ambos (SCHYNS \& SCHILLING, 2013). Trabalhadores que interagem com líderes inautênticos, sentem-se exaustos emocionalmente e, como mecanismo de defesa, silenciam-se e passam a evitá-los no ambiente laboral (XU et al, 2015).

Para Kellerman (2004), líderes imorais, ou também citados por ela como "líderes tóxicos", podem ser divididos em quatro grandes grupos, sendo o primeiro os indiferentes as necessidades e ao bem-estar de seus seguidores. O segundo seriam os desequilibrados que falham no controle de seus próprios impulsos. O terceiro refere-se aos corruptos que infringem as regras de boa convivência e sugam recursos que deveriam ser compartilhados pela coletividade. E por último, sendo este o que promove o maior desgaste emocional entre os trabalhadores, seriam aqueles que pressionam psicologicamente seus subordinados e apresentam um certo grau de sordidez no prolongamento desse sofrimento (KELLERMAN, 2004).

Quando se analisa a literatura sobre a má liderança organizacional, percebese um campo, até o presente, pouco explorado e, apesar de haver publicações sobre o tema nas últimas décadas em periódicos internacionais de primeira linha, há uma quantidade ainda incipiente de trabalhos que investigam o impacto negativo desses profissionais em ambientes corporativos (EINARSEN et al, 2007). Entretanto, de um modo geral, percebe-se na literatura da área um conjunto de pesquisas que abrange duas vertentes: de um lado, estudos que buscam tratar 
de características gerais da má liderança, como seriam os casos de líderes tóxicos (KELLERMAN, 2004; PELLETIER, 2012) e líderes destrutivos (SHAW et al, 2011; SCHYNS \& SCHILLING, 2013). E, do outro, estudos que enfatizam comportamentos específicos desses indivíduos antiéticos, através de ações implícitas e do uso sútil das emoções a fim de manipular seu público de interesse (RAJAH et al, 2011), ou através de ações explícitas, como a hostilidade contra seus subordinados e pela imposição de seu poder opressor de maneira tirânica (NASEER et al, 2015).

Do ponto de vista das ações específicas destes líderes tóxicos, dois tipos de condutas podem ser identificados. Por um lado, a má liderança que se apresenta de maneira mais discreta, como no caso do líder manipulador, que pratica a hipocrisia através da construção de uma imagem eticamente aceita, mas que de forma oculta, preserva interesses pessoais em detrimento dos coletivos (RUBIN et $a l$, 2009). São os corruptos que agem silenciosamente extorquindo recursos escassos que deveriam ser compartilhados por todos (NEAL \& TANSEY, 2010). Outros exemplos presentes na literatura seriam os líderes maquiavélicos (DELUGA, 2001), cínicos (NEVES, 2012) e narcisistas (O’REILLY III et al, 2014). No segundo grupo, a liderança má se revela de forma mais clara e explícita. É o líder autoritário e opressor que age de maneira tirânica e inflexível. Inflados em sua arrogância, estes indivíduos negligenciam as ideias de seus seguidores que poderiam lhes auxiliar frente suas empreitadas (XU et al, 2015). Exemplos presentes na literatura seriam os líderes déspotas (NASEER et al, 2015), tirânicos (KANT et al, 2013) e abusivos (HARVEY et al, 2014).

Assim, como forma de situar o leitor ao campo de estudo, está exposto no Quadro 1, alguns dos trabalhos mais importantes nestes últimos anos que investigaram e colaboraram com o avanço teórico sobre a má liderança. Apesar dos rótulos aplicados ao líder mau variarem entre as pesquisas, de acordo com atributos comportamentais específicos, todos eles complementam o desenvolvimento da literatura na área. Vale ressaltar que o quadro a seguir é limitado aos artigos publicados no The Leadership Quarterly, renomado periódico internacional que tem como escopo o estudo da liderança nas organizações. 
Quadro 1 - Estudos sobre Má Lideraça nos últimos anos

\begin{tabular}{|c|c|c|c|}
\hline Ano & Autor (es) & Título & Palavras-Chave \\
\hline 2010 & Neal \& Tansey & $\begin{array}{c}\text { A dinâmica da liderança corrupta eficaz: lições da carreira } \\
\text { política de Rafik Hariri no Líbano }\end{array}$ & $\begin{array}{c}\text { Liderança; Corrupção; Eficácia; } \\
\text { Política }\end{array}$ \\
\hline \multirow{5}{*}{2011} & $\begin{array}{l}\text { Nevicka, Hoogh, Vianen, } \\
\text { Beersma \& Mcllwain }\end{array}$ & Manifestações e performance do líder narcisista & $\begin{array}{l}\text { Liderança; Manifestação; Narcisismo; } \\
\text { Performance Organizacional }\end{array}$ \\
\hline & Harris, Harvey \& Kacmar & $\begin{array}{l}\text { Reações da supervisão abusiva nos relacionamentos e } \\
\text { conflitos entre trabalhadores }\end{array}$ & $\begin{array}{c}\text { Supervisão Abusiva; Conflitos; } \\
\text { Organizações }\end{array}$ \\
\hline & Shaw, Erickson \& Harvey & $\begin{array}{c}\text { Método para mensurar e identificar tipos de líderes } \\
\text { destrutivos nas organizações }\end{array}$ & $\begin{array}{c}\text { Liderança Destrutiva; Tipologias; } \\
\text { Organizações }\end{array}$ \\
\hline & Harms, Spain \& Hannah & $\begin{array}{l}\text { Desenvolvimento de líderes e o lado obscuro de sua } \\
\text { personalidade }\end{array}$ & $\begin{array}{l}\text { Liderança; Desenvolvimento; } \\
\text { Personalidade }\end{array}$ \\
\hline & $\begin{array}{c}\text { Martinko, Harvey, Sikora } \\
\text { \& Douglas }\end{array}$ & $\begin{array}{c}\text { Percepções da supervisão abusiva: o papel dos estilos de } \\
\text { atribuições dos subordinados }\end{array}$ & $\begin{array}{l}\text { Supervisão Abusiva; Atribuições; } \\
\text { LMX }\end{array}$ \\
\hline
\end{tabular}




\begin{tabular}{|c|c|c|c|}
\hline \multirow{2}{*}{2012} & Neves & $\begin{array}{l}\text { Cinismo organizacional: efeitos nas relações e } \\
\text { performance de líderes e seguidores }\end{array}$ & $\begin{array}{l}\text { Liderança; Cinismo; Relações; } \\
\text { Performance Organizacional }\end{array}$ \\
\hline & Pelletier & $\begin{array}{c}\text { Reações e percepções a toxicidade de líderes nas relações } \\
\text { organizacionais }\end{array}$ & $\begin{array}{l}\text { Liderança Tóxica; Reações de } \\
\text { Subordinados; LMX }\end{array}$ \\
\hline \multirow{2}{*}{2013} & $\begin{array}{l}\text { Kant, Skogstad, Torsheim } \\
\text { \& Einarsen }\end{array}$ & $\begin{array}{l}\text { Cuidado com líderes agressivos: traços da agressividade e } \\
\text { ansiedade como preditores da liderança tirânica }\end{array}$ & $\begin{array}{c}\text { Supervisão Abusiva; Traços da } \\
\text { Agressividade; Traços da Ansiedade; } \\
\text { Tirania Organizacional }\end{array}$ \\
\hline & Schyns \& Schilling & $\begin{array}{c}\text { Metánalise sobre a liderança destrutiva e suas } \\
\text { consequências }\end{array}$ & $\begin{array}{c}\text { Liderança Destrutiva; Consequências; } \\
\text { Metánalise }\end{array}$ \\
\hline \multirow{2}{*}{2014} & $\begin{array}{l}\text { O'Reilly III; Doerr; } \\
\text { Caldwell; Chatman }\end{array}$ & CEOs narcisistas e compensação executiva & $\begin{array}{l}\text { Liderança; Narcisismo; CEO; } \\
\text { Compensação Executiva }\end{array}$ \\
\hline & $\begin{array}{l}\text { Harvey, Harris, Gillis \& } \\
\text { Martinko }\end{array}$ & Supervisão abusiva e trabalhadores intitulados & $\begin{array}{l}\text { Supervisão Abusiva; Intitulação; } \\
\text { Organizações }\end{array}$ \\
\hline \multirow[t]{2}{*}{2015} & $\begin{array}{l}\text { Naseer, Raja, Syed, } \\
\text { Donia \& Darr }\end{array}$ & $\begin{array}{l}\text { Perigos em estar perto de líderes e ambientes ruins: } \\
\text { explorando a combinação de efeitos da liderança } \\
\text { despótica, LMX e as políticas de percepção nos } \\
\text { comportamentos organizacionais }\end{array}$ & $\begin{array}{c}\text { Liderança Despótica; LMX; } \\
\text { Comportamento de Cidadania } \\
\text { Organizacional }\end{array}$ \\
\hline & Xu, Loi \& Lam & $\begin{array}{c}\text { Interação entre supervisão abusiva e LMX como preditores } \\
\text { do silêncio organizacional entre trabalhadores }\end{array}$ & $\begin{array}{l}\text { Supervisão Abusiva; LMX; Silêncio } \\
\text { Organizacional; Exaustão Emocional }\end{array}$ \\
\hline
\end{tabular}

Fonte: elaborado pelo autor. 


\section{3 Emoções}

O estudo das emoções é particularmente recente na área de comportamento organizacional. Até meados da década de 1990, não se existia na literatura um corpo teórico fundamentado sobre o papel das emoções na gestão organizacional, tendo sido ela um tema de interesse da psicologia (FINEMAN, 2006). Entretanto, nas últimas décadas, houve um crescimento substancial em pesquisas que tem analisado as emoções em ambientes empresariais, principalmente em estudos que as relacionam com a liderança, em sua maioria buscando compreender a importância do seu papel para o desenvolvimento de líderes de sucesso, carismáticos e transformacionais (BONO \& ILIES, 2006).

As emoções estão presentes em todas as dimensões da vida humana e em qualquer atividade social, inclusive na liderança, cuja manifestação pode partir do indivíduo, entre equipes, ou em nível organizacional (ASHAKANASY \& HUMPHREY, 2011). O seu campo de estudo é vasto inexistindo, ainda, em âmbito acadêmico, um consenso conceitual acerca das principais terminologias da área, como afetividade, sentimento, emoções e humor (FINEMAN, 2001).

A afetividade, popularmente conhecida como "sentimento", surge como o termo generalizado que define uma ampla extensão de sensações neurofisiológicas, em que as pessoas experimentam através de emoções e pelo humor (EKKEKAKIS, 2013). Este estado afetivo pode ou não se manifestar através de uma situação específica, e o indivíduo pode senti-lo tanto de maneira positiva, gozando de bem-estar, como de forma negativa, sofrendo estresse e sensações desagradáveis (EKKEKAKIS, 2013).

As emoções são entendidas como sensações intensas, de curta duração e causadas por alguém ou por algo em particular. São reações automáticas e inconscientes, manifestadas através de expressões corporais e comportamentais, e de natureza específica, como a alegria, raiva ou surpresa (FRIJDA, 2009). Já o humor apresenta baixa intensidade e dura mais que as emoções. Geralmente não é desencadeado por uma única causa e sua natureza é ampla, composta de diversas emoções, e o indivíduo pode estar ou não consciente de seu estado psicológico. Alguns exemplos são a animação, ansiedade ou desânimo (FRIJDA, 2009).

Assim como o afeto, as emoções apresentam dimensões positivas e negativas, e podem manifestar-se em conjunto, como é o caso do amor, que está 
sintonizado com a felicidade e satisfação, ou a depressão, cujo quadro psicológico compõe-se do medo e da tristeza (FINEMAN, 2006).

Segundo Izard (2009), pesquisador comportamental que tem se dedicado há anos ao tema, certas emoções estão integradas a processos referentes a cognição humana. Assim, elas estariam divididas em dois grandes grupos. O primeiro diz respeito às emoções básicas, primárias ou não cognitivas, estando presentes no ser humano desde o início de sua evolução e funcionando como impulsos inconscientes frente à adaptação e sobrevivência da espécie, sendo o medo e a tensão exemplos fáceis de identificar. Já o segundo grupo inclui as emoções secundárias, cognitivas ou programadas, conectadas às áreas da consciência e percepção humana, e que são exteriorizadas de forma pensada, como a admiração, a serenidade ou a inveja (IZARD, 2009).

Além das emoções primárias e secundárias, elas também podem ser classificadas quanto aos seus níveis de moralidade e interpessoalidade. No primeiro, têm-se as emoções morais, fonte primordial de líderes éticos, servidores e autênticos (MICHIE \& GOOTY, 2005). São os casos da vergonha e culpa, que um indivíduo pode vir a sentir após desvios de conduta, ou o egoísmo, provável característica psicológica do líder antiético. Já em líderes íntegros, emoções como a compaixão, respeito e empatia são típicas deste indivíduo que promove o bemcomum. No caso das emoções interpessoais, englobam-se todas aquelas que afetam o comportamento social entre dois ou mais indivíduos, como é o caso da gratidão ou do ciúme (KLEEF, 2009).

As emoções interpessoais impactam sobremaneira as relações profissionais nas empresas, cujo fenômeno tem despertado o desenvolvimento de diferentes teorias no meio acadêmico. Dentre elas, destaca-se a teoria que analisa as emoções como informações sociais (KLEEF, 2009). De acordo com o conceito, as emoções possuem a capacidade de alterar o comportamento afetivo e a percepção racional que uma pessoa tem sobre a outra quando estão se relacionando, sendo o primeiro caso constatado pelo processo inconsciente que levam seguidores a se contagiarem por emoções expressas por seus líderes, se afeiçoando ou não a eles (TEE, 2015). Já no segundo caso, destaca-se a avaliação consciente que as pessoas fazem destes líderes quando eles manifestam determinadas emoções em contextos organizacionais variados. Quando externalizadas de maneira inoportuna, eles 
tendem a ser julgados como incompetentes. Do contrário, podem ser percebidos como profissionais de sucesso (MADERA \& SMITH, 2009).

\section{4 \\ Liderança e Emoções}

No cenário competitivo atual, marcado por intensa volatilidade, habilidades de relacionamento interpessoal tornam-se indispensáveis para o líder que precisa compreender as transformações organizacionais e promover a necessária adaptação de seus trabalhadores (GOOTY et al, 2010). Este indivíduo que possui a responsabilidade de orientar pessoas necessita dominar conhecimentos relacionados a cognição e afetividade humana, expressados através de comportamentos e emoções, a fim de explorá-las ao máximo em proveito das relações profissionais (GOOTY et al, 2010).

A boa liderança passa pela competência destes indivíduos em construírem ambientes que propiciem uma sincronia emocional entre seus liderados (MCCOLL-KENNEDY \& ANDERSON, 2002). Como uma espécie de gestor emocional, utiliza de sua percepção apurada para identificar o estado de ânimo de sua equipe e, caso necessário, age em prol da mudança e da prevenção de quadros emocionais negativistas (ANTONAKIS et al, 2009). Assim, conhecendo as causas que afetam o ânimo de seus seguidores, o líder eficaz buscaria comunicar-se emocionalmente de tal forma que os impactasse profundamente, restaurando um estado psicológico que antes era desfavorável, por um novo, positivo e conveniente ao momento (ASHAKANASY \& HUMPHREY, 2011).

Desta forma, constata-se que as emoções têm papel importante nas relações profissionais e, por esta razão, devem ser exploradas de maneira responsável, orientadas por uma conduta moral que vise o bem comum, ao invés de interesses particulares (BALLINGER et al, 2009). Entretanto, quando valores e discursos defendidos por um líder não se ajustam com suas ações, este irá perder a confiança necessária para se construir boas relações com seus subordinados transformando-se em um líder tóxico e destrutivo (KELLERMAN, 2004).

Exemplos destes tipos de profissionais estão dispersos por toda a sociedade, nas esferas públicas e privadas, além de contribuírem com o atraso econômico e social (GARDNER, 1995). De forma despreocupada quanto a consequência de seus atos, eles agem de diversas formas, encobrindo sua real personalidade através 
da manipulação pessoal ou demonstrando-a de maneira extrema, conduzindo agressivamente seus seguidores e promovendo hostilidade no ambiente de trabalho (KANT et al 2013; NEVES, 2012).

Assim, percebe-se que a má liderança é influenciada por um conjunto de fatores que conduzem à incompetência do líder enquanto agente responsável pela orientação de pessoas (KELLERMAN, 2004). Um destes fatores diz respeito ao mau uso que fazem das emoções, como instrumentos para facilitar atividades fraudulentas e de ludíbrio ao próximo (PADILLA et al, 2007).

Conscientes do poder que as emoções podem trazer para uma comunicação persuasiva, estes líderes as exploram intensamente e por diferentes formas, como através de expressões corporais e faciais diversas, pelo timbre de voz, e por discursos efusivos, repletos de metáforas e parábolas emocionais (ANTONAKIS, 2012). Pesquisas têm comprovado que as expressões faciais manifestadas por estes líderes impactam a percepção que seus observadores terão de seu potencial enquanto profissionais (OLIVOLA et al, 2014; TRICHAS \& SCHYNS, 2012). E isto é particularmente importante em determinadas emoções, manifestadas por expressões faciais específicas, pois influenciarão o julgamento de ética que seguidores farão sobre este líder organizacional, além da credibilidade e percepção de eficácia depositadas sobre ele (TEE, 2015).

Um estudo interessante, realizado entre diferentes culturas, demonstrou que quando um líder externalizava emoções empáticas e estas eram percebidas pelos seus subordinados, estes tendiam a fazer uma avaliação mais favorável quanto ao desempenho desse profissional (SADRI et al, 2011). Em outra pesquisa, líderes éticos que demonstravam essas emoções, e eram comparados com líderes despóticos, obtiveram avaliações superiores como gestores de equipes, além de terem sido considerados catalisadores de otimismo entre seus seguidores em relação ao futuro da organização (HOOGH \& HARTOG, 2008).

De acordo com o trabalho de Johnson (2008), sobre contágio e emoções, foi constatado que quando um líder manifestava emoções positivas como alegria ou amor em seu ambiente de trabalho, seus seguidores se contagiavam com ele e, na maioria dos casos, se identificavam pessoalmente e apresentavam comportamentos de cidadania organizacional (JOHNSON, 2008).

Em uma pesquisa recente de Visser et al (2013), os autores comprovaram que quando líderes expressavam emoções de alegria e tristeza em seus cotidianos 
laborais, seus subordinados avaliavam aqueles que externalizavam a alegria como sendo profissionais que possuíam uma performance superior em relação aos que apresentavam a tristeza, além de estimularem a criatividade entre esses trabalhadores (VISSER et al, 2013). Em outro estudo, foi confirmado ainda o impacto que emoções positivas como a alegria e expressões carismáticas, como sorrisos e contato visual atencioso, podem ter na avaliação favorável de eficácia de um líder, além da identificação pessoal com ele, em contraste com emoções negativas como a tristeza e expressões de desânimo, como postura visual cabisbaixa e ausência de sorrisos (BONO \& ILIES, 2006).

Quando se comparam emoções negativas como tristeza e raiva, Madera \& Smith (2009) identificaram em seu estudo que líderes que manifestavam tristeza em um contexto de crise organizacional eram avaliados de modo mais favorável quanto a sua performance do que aqueles que externalizavam agressividade (MADERA \& SMITH, 2009). Existem ainda pesquisas que constataram que líderes que apresentavam traços de agressividade eram mais facilmente percebidos como pessoas tirânicas que promoviam hostilidade entre subordinados e que estimulavam atitudes de bullying organizacional, comportamentos estes que estão longe de se harmonizarem com os atributos de uma liderança ética e autêntica (KANT et al, 2013; MATTHIESEN \& EINARSEN, 2007).

Entretanto, de uma forma geral, tanto líderes homens como mulheres que manifestam emoções negativas passivas e agressivas no ambiente laboral têm sido percebidos como profissionais incompetentes (LEWIS, 2000). Por outro lado, líderes alegres que externalizam emoções positivas têm recebido melhores avaliações comportamentais em relação a seu desempenho e à identificação pessoal com ele (JOSEPH et al, 2015; JOHNSON, 2008; BONO \& ILIES, 2006).

Tendo em vista o que foi dito, entende-se que as emoções influenciam significativamente as relações profissionais no espaço organizacional e suas diferentes dimensões, como contágio emocional, avaliação de competência, percepção da conduta ética, identificação pessoal, relações de confiança, dentre outras (RAJAH et al, 2011). Desta forma, este trabalho buscou investigar o impacto que as expressões emocionais de um líder inautêntico poderiam causar na percepção de eficácia, julgamento ético e identificação pessoal de seguidores ao se atentarem a um discurso antiético proferido por este indivíduo. 
Em seguida, está exposta a Figura 1 representando o modelo geral da pesquisa seguido das hipóteses do estudo.

Figura 1 - Modelo Geral da Pesquisa

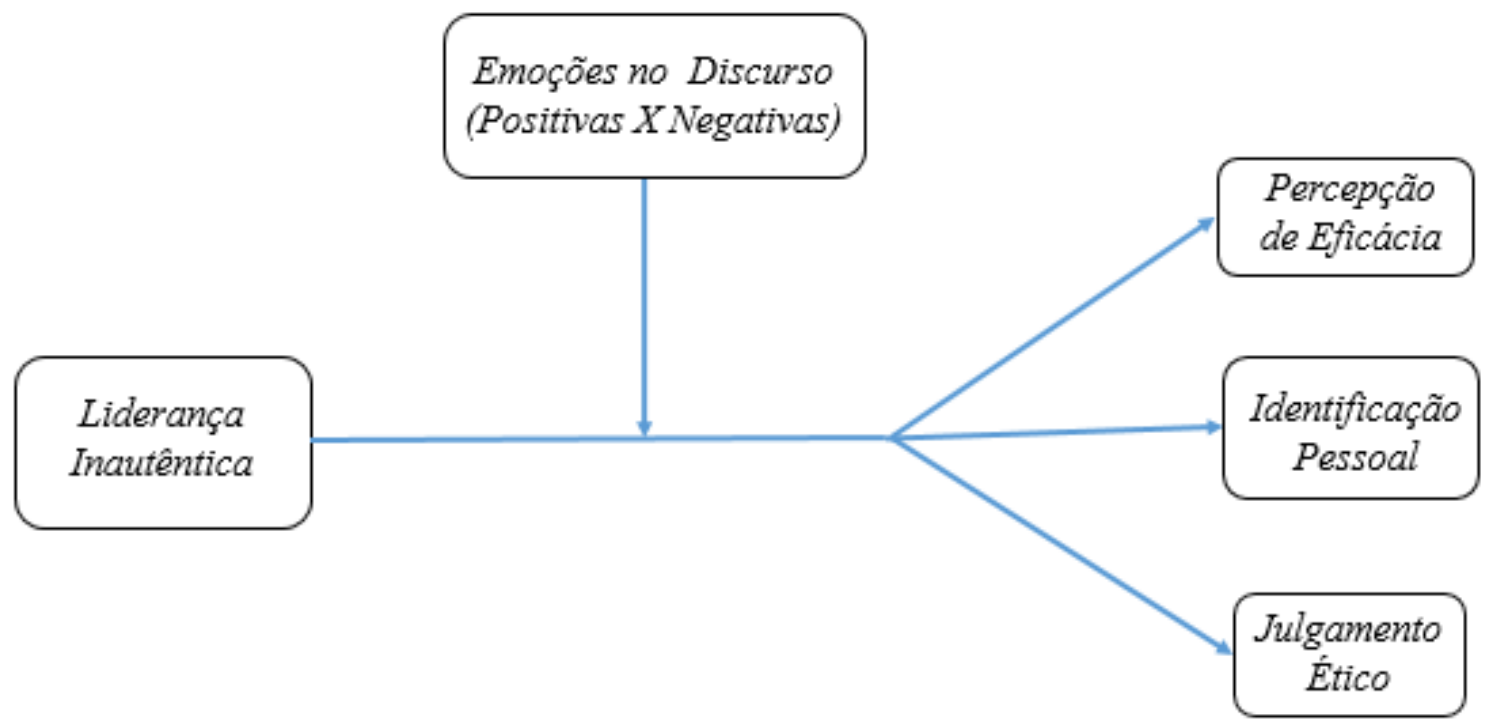

Fonte: elaborado pelo autor.

As hipóteses buscaram testar o efeito que expressões emocionais positivas (alegria) e negativas (tristeza e raiva) de um líder inautêntico teriam na percepção de eficácia, julgamento ético e identificação pessoal dos seguidores com esse profissional. Assim, foram desenvolvidas nove hipóteses, sendo agrupadas em três grupos de três hipóteses cada representando sempre a comparação entre duas emoções e os construtos analisados.

\section{Grupo 1 - Emoção Negativa Passiva X Emoção Positiva}

H1a: Seguidores de um líder inautêntico que expressa afetividade negativa passiva (tristeza) tendem a julgá-lo como menos eficaz do que aquele que expressa afetividade positiva (alegria).

H1b: Seguidores de um líder inautêntico que expressa afetividade negativa passiva (tristeza) tendem a se identificar menos com esse líder do que com aquele que expressa afetividade positiva (alegria). 
H1c: Seguidores de um líder inautêntico que expressa afetividade negativa passiva (tristeza) tendem a julgá-lo como menos ético do que aquele que expressa afetividade positiva (alegria).

\section{Grupo 2 - Emoção Negativa Agressiva X Emoção Positiva}

H2a: Seguidores de um líder inautêntico que expressa afetividade negativa agressiva (raiva) tendem a julgá-lo como menos eficaz do que aquele que expressa afetividade positiva (alegria).

H2b: Seguidores de um líder inautêntico que expressa afetividade negativa agressiva (raiva) tendem a se identificar menos com esse líder do que com aquele que expressa afetividade positiva (alegria).

H2c: Seguidores de um líder inautêntico que expressa afetividade negativa agressiva (raiva) tendem a julgá-lo como menos ético do aquele que expressa afetividade positiva (alegria).

\section{Grupo 3 - Emoção Negativa Agressiva X Emoção Negativa Passiva}

H3a: Seguidores de um líder inautêntico que expressa afetividade negativa agressiva (raiva) tendem a julgá-lo como menos eficaz do que aquele que expressa afetividade negativa passiva (tristeza).

H3b: Seguidores de um líder inautêntico que expressa afetividade negativa agressiva (raiva) tendem a se identificar menos com esse líder do que com aquele que expressa afetividade negativa passiva (tristeza).

H3c: Seguidores de um líder inautêntico que expressa afetividade negativa agressiva (raiva) tendem a julgá-lo como menos ético do aquele que expressa afetividade negativa passiva (tristeza). 


\section{3 \\ Metodologia de Estudo}

O presente estudo é baseado na metodologia de experimento, com o objetivo de analisar se as expressões emocionais de um líder inautêntico interferem nos julgamentos sobre seu desempenho, conduta ética e identificação pessoal de observadores com esse profissional. Os procedimentos metodológicos são inspirados na pesquisa de Turano (2015) que investigou o impacto de valores autênticos no discurso de um líder e como suas expressões emocionais afetariam a percepção de eficácia de seus seguidores em relação a esse profissional.

\section{1 \\ Procedimento}

O experimento se desenvolveu através da atuação de um ator profissional que fora contratado para representar um CEO fictício de um suposto grupo empresarial e manipular um discurso utilizando-se de emoções positivas, negativas e neutras. Assim, foram gravados quatro vídeos, nos quais o conteúdo do discurso do líder era o mesmo, porém, a expressão emocional do líder variava em cada vídeo em dimensões positivas (vídeo A - alegria), negativas agressivas (vídeo $\mathrm{B}$ - raiva), negativas passivas (vídeo $\mathrm{C}$ - tristeza) e emoções neutras (vídeo D) (ver apêndice 2). O texto do discurso exibido pelo ator foi desenvolvido com base nas subdimensões da liderança autêntica da escala ALQ (Authentic Leadership Questionnaire) de Walumbwa et al (2008), distribuído por Mind Garden, Inc. (www.mindgarden.com). Como o instrumento mede características autênticas de um líder, estes atributos foram invertidos transformando-os em princípios inautênticos e adaptando-os sob a forma de afirmações no discurso, com o cuidado de manter a naturalidade das falas do ator (ver apêndice 1).

Em seu discurso, o CEO fictício apresenta a empresa aos expectadores e a partir do meio do vídeo, expressa inautenticidade, defendendo o não compartilhamento de informações e a manipulação da imagem da companhia (falta de transparência), a busca pelos próprios interesses em detrimento dos coletivos e sociais (visão egocentrada e ausência de responsabilidade socioambiental), o uso intensivo da autoridade e controle sobre os trabalhadores (liderança tóxica e pouco participativa) e a busca de resultados acima de tudo estimulando um clima de desvalorização de ideias e colaboração no trabalho. 


\section{2}

\section{Coleta de Dados}

Os dados foram coletados junto a universitários que cursavam graduação em Administração de Empresas na modalidade de Educação a Distância (EaD). Estes estudantes faziam parte do CEDERJ (Centro de Educação Superior a Distância do Estado do Rio de Janeiro), sendo este um consórcio de seis universidades públicas e um centro universitário (UERJ, UENF, UNIRIO, UFRJ, UFF, UFRRJ e CEFET-RJ) e que em parceria com a Fundação CECIERJ oferta graduações em EaD por todo Rio de Janeiro.

O instrumento de coleta de dados foi preenchido pelos participantes por meio de um questionário eletrônico construído no Qualtrics (www.qualtrics.com) e seus dados foram analisados no software estatístico SPSS (Statistical Package for the Social Sciences). Como forma de aperfeiçoamento, o mesmo passou por um pré-teste com 20 estudantes que apresentaram pequenas sugestões e colaboraram com melhorias. O convite para participar da pesquisa foi encaminhado por email a todos os estudantes de Administração de Empresas do CEDERJ, cujos endereços eletrônicos encontravam-se disponíveis em sua plataforma virtual de ensino (www.cederj.edu.br), principal ambiente de realização das atividades educacionais. Desta forma, cada um dos 4.555 estudantes matriculados no CEDERJ recebeu em seu correio eletrônico uma mensagem solicitando a sua participação na pesquisa e contendo um link que o direcionava diretamente ao questionário hospedado no site do Qualtrics. Assim, buscou-se atingir o maior número de respondentes dentro do prazo estabelecido para a coleta de dados, que foi de três semanas.

O questionário apresentava inicialmente instruções de preenchimento e, em seguida, apenas um dos quatro vídeos da pesquisa, randomizado pelo software Qualtrics. Os vídeos duravam entre 1:20 e 1:40 minutos, sendo o vídeo A, 1:36, o vídeo $\mathrm{B}, 1: 24$, o vídeo $\mathrm{C}, 1: 39$ e o vídeo $\mathrm{D}, 1: 27$. Depois de assistido o vídeo, o participante deveria responder a cinco seções, cada uma contendo uma escala específica que buscava mensurar os construtos necessários a essa pesquisa, a saber: Escala de Estados Afetivos Transitórios do Líder; Escala de Percepção de Eficácia do Líder; Escala de Identificação Pessoal com o Líder; Escala de Percepção de Liderança Ética do Líder; Escala de Percepção de Liderança 
Autêntica do Líder; e Escala de Nível de Desenvolvimento Moral do Entrevistado. Por último, questões demográficas como sexo, idade, experiência profissional, período e coeficiente de rendimento (CR) acadêmico foram incluídas a fim de se levantar informações a respeito das características pessoais dos entrevistados (ver apêndice 3).

\section{3 \\ Escalas de Mensuração}

Estados Afetivos Transitórios do Líder - Optou-se pela utilização da escala POMS (Profile of Mood States) de 15 itens desenvolvida por McNair et al (1992). Esta métrica foi usada com o intuito de se avaliar pelos seguidores o estado de humor e emocional do líder. Ela contém itens como "O líder parece alegre" e "O líder parece desanimado". Participantes avaliaram o estado afetivo do líder com base em uma escala de 7 pontos (de $1=$ Totalmente Incorreto até $7=$ Totalmente Correto). O Alpha de Cronbach desta escala é de 0,82.

Percepção de Eficácia do Líder - Foram elaborados três itens que visavam avaliar a percepção do seguidor em relação a eficácia do líder. Os itens que compõe esta escala são: "Esse CEO é um bom líder", "Eu me dedicaria mais e aumentaria minha produtividade com um líder como esse" e "Eu acredito que esse líder teria um alto desempenho na área em que trabalho". Participantes avaliaram suas percepções de eficácia por meio de uma escala Likert de 5 pontos (de $1=$ Discordo Totalmente até $5=$ Concordo Totalmente). O Alpha de Cronbach desta escala é de 0,92 .

Identificação Pessoal com o Líder - Foram elaborados três itens que buscaram avaliar o grau de identificação do seguidor com o líder analisado. São eles: "Esse CEO corresponde à imagem que eu tenho de um líder", "Eu me identifico com esse líder" e "Eu gostaria de ter esse CEO como líder formal (chefe) ". Os entrevistados atribuíram seu grau de identificação com o líder por meio de uma escala Likert de 5 pontos de 5 pontos (de $1=$ Discordo Totalmente até $5=$ Concordo Totalmente). O Alpha de Cronbach desta escala é de 0,89.

Percepção de Liderança Ética do Líder - Optou-se pela utilização da escala ELS (Ethical Leadership Scale) de 10 itens desenvolvida por Brown et al (2005). 
O objetivo era avaliar a percepção dos seguidores quanto a personalidade do líder no que diz respeito à ética. Ela contém itens como "O líder conduz sua vida pessoal de maneira ética" e "O líder dá o exemplo de como fazer as coisas de maneira correta sob o ponto de vista ético". Participantes avaliaram a conduta ética do líder por meio de uma escala de 7 pontos (de 1 = Discordo Totalmente até 7 = Concordo Totalmente). O Alpha de Cronbach desta escala é de 0,85.

Percepção de Liderança Autêntica do Líder - Adotou-se a escala ALQ (Authentic Leadership Questionnaire) desenvolvida por Walumbwa et al (2008). Esta métrica buscou avaliar o grau de autenticidade do líder percebido pelos seguidores, sendo composta de 16 itens que refletem as quatro dimensões propostas pela teoria (autoconsciência, internalização dos princípios morais, processamento balanceado e relacionamento transparente). Alguns exemplos de itens são: "O líder diz exatamente o que pensa" (relacionamento transparente) e "O líder toma decisões com base nos seus valores centrais" (internalização dos princípios morais). Participantes avaliaram a conduta autêntica do líder por meio de uma escala de 5 pontos (de $1=$ Nunca até $5=$ Frequentemente, se não sempre). O Alpha de Cronbach desta escala é de 0,95.

Nível de Desenvolvimento Moral do Entrevistado - Como forma de se avaliar o nível de desenvolvimento moral dos participantes, adotou-se a escala de Stohs \& Brannick (1996), criada com o intuito de analisar a ética de indivíduos em ambientes de negócio. Este instrumento se baseia em sete cenários fictícios contendo dilemas éticos, cujos entrevistados teriam que analisá-los baseando-se em seus valores sobre o que consideram moralmente correto. A avaliação da percepção moral dos entrevistados foi realizada por meio de uma escala de seis pontos (de 1 = Extremamente Inaceitável até $6=$ Extremamente Aceitável). O Alpha de Cronbach desta escala é de 0,79 .

Dados Demográficos - Foram solicitados aos entrevistados que respondessem questões referentes ao sexo, idade, experiência profissional, período e CR acadêmico, a fim de que essas perguntas fossem utilizadas como controle para o experimento e como forma de garantir a homogeneidade dos quatro grupos analisados (que assistiram aos vídeos A, B, C ou D). 


\section{4}

\section{Amostra}

O processo de amostragem foi não probabilístico e por conveniência. Do total de 4.555 emails enviados, 291 foram respondidos, sendo eliminados 16 participantes em função de problemas não recuperáveis de preenchimento de formulários. Assim, a amostra utilizada foi de 275 respondentes, cuja distribuição aleatória pelos quatro vídeos mostrou-se equilibrada: 68 viram o vídeo A, 70 o vídeo $\mathrm{B}, 73$ o vídeo C e 64 o vídeo D.

Quanto a análise dos dados demográficos, verifica-se pelo Quadro 2 que não há diferença entre os quatro grupos resultando em uma distribuição equilibrada. Dos 275 participantes, pouco mais da metade são homens (56\%) e 44\% mulheres. A média da faixa etária está acima dos 30 anos (32 anos) e são profissionais maduros, com uma taxa média de experiência de mercado acima dos 10 anos (11 anos). O rendimento acadêmico mostrou-se razoável $(6,7)$ e estavam, em média, quase na metade do curso ( $4^{\circ}$ período).

Quadro 2 - Estatística Demográfica por Vídeo

\begin{tabular}{|c|c|c|c|c|}
\hline \multirow{2}{*}{ Variável } & Alegre & Agressivo & Triste & Neutro \\
\hline \multirow{2}{*}{ Sexo } & $41,1 \% \mathrm{~F}$ & $41,4 \% \mathrm{~F}$ & $39,7 \% \mathrm{~F}$ & $53,1 \% \mathrm{~F}$ \\
\cline { 2 - 5 } & $58,9 \% \mathrm{M}$ & $58,6 \% \mathrm{M}$ & $60,3 \% \mathrm{M}$ & $46,9 \% \mathrm{M}$ \\
\hline \multirow{2}{*}{ Idade } & $\bar{x}=33,7$ & $\bar{x}=32,0$ & $\bar{x}=33,2$ & $\bar{x}=32,5$ \\
\cline { 2 - 5 } & $\mathrm{DP}=10,7$ & $\mathrm{DP}=9,0$ & $\mathrm{DP}=9,2$ & $\mathrm{DP}=8,6$ \\
\hline \multirow{2}{*}{ Período } & $\bar{x}=4,0$ & $\bar{x}=3,9$ & $\bar{x}=4,2$ & $\bar{x}=4,4$ \\
\cline { 2 - 5 } & $\mathrm{DP}=2,7$ & $\mathrm{DP}=2,5$ & $\mathrm{DP}=2,8$ & $\mathrm{DP}=3,1$ \\
\hline \multirow{2}{*}{ Experiência } & $\bar{x}=12,5$ & $\bar{x}=11,5$ & $\bar{x}=11,3$ & $\bar{x}=10,2$ \\
\cline { 2 - 5 } & $\mathrm{DP}=10,8$ & $\mathrm{DP}=9,1$ & $\mathrm{DP}=8,9$ & $\mathrm{DP}=7,6$ \\
\hline \multirow{2}{*}{$\mathrm{CR}$} & $\bar{x}=6,9$ & $\bar{x}=6,5$ & $\bar{x}=6,7$ & $\bar{x}=6,6$ \\
\cline { 2 - 5 } & $\mathrm{DP}=1,3$ & $\mathrm{DP}=1,8$ & $\mathrm{DP}=1,6$ & $\mathrm{DP}=1,5$ \\
\hline \multirow{2}{*}{ Respondente } & 68 Profissionais & 70 Profissionais & 73 Profissionais & 64 Profissionais \\
\hline
\end{tabular}

Fonte: elaborado pelo autor. 


\section{4}

\section{Análise dos Resultados}

\section{1}

\section{Desenvolvimento Moral dos Entrevistados}

$\mathrm{Na}$ primeira etapa da análise, compararam-se as médias das amostras em relação ao desenvolvimento moral dos entrevistados a fim de se verificar se houve diferença significativa nos grupos investigados no que diz respeito às características morais dos respondentes. Percebe-se pelo Quadro 3 que não houve diferença significativa $(\mathrm{F}=0,701, \mathrm{p}>0,05)$ entre os quatro grupos investigados após a realização do teste da análise da variância (ANOVA) e da comparação de médias pelo teste Tukey HSD. Assim, os grupos mostraram-se equivalentes não indicando quaisquer diferenças quanto as suas características morais.

Quadro 3 - ANOVA - Desenvolvimento Moral dos Entrevistados

\begin{tabular}{|c|c|c|c|}
\hline \multicolumn{2}{|c|}{ ANOVA } & \multicolumn{2}{c|}{ Teste Tukey HSD } \\
\hline \multirow{2}{*}{ F } & \multirow{2}{*}{ Sigma } & Vídeos & Médias Individuais (Sigma = 0,05) \\
\hline \multirow{2}{*}{0,701} & \multirow{2}{*}{0,552} & Negativo Agressivo & 2,24 \\
\cline { 3 - 4 } & & Neutro & 2,25 \\
\cline { 3 - 4 } & & Negativo Passivo & 2,37 \\
\cline { 3 - 4 } & & Positivo & 2,39 \\
\hline
\end{tabular}

Fonte: elaborado pelo autor.

\section{2}

\section{Efeito da Manipulação das Expressões Emocionais}

$\mathrm{Na}$ segunda etapa da análise, buscou-se testar o efeito da manipulação das expressões emocionais do líder inautêntico sobre a percepção dos entrevistados. Assim, através da ANOVA e da comparação de médias pelo teste Tukey HSD, foi verificado se os entrevistados que assistiram ao vídeo do líder inautêntico expressando afetividade positiva (alegria) perceberam de fato esse indivíduo como uma pessoa alegre, se os entrevistados que assistiram ao vídeo do líder inautêntico expressando afetividade negativa agressiva (raiva) perceberam de fato esse indivíduo como uma pessoa raivosa, se os entrevistados que assistiram ao vídeo 
do líder inautêntico expressando afetividade negativa passiva (tristeza) perceberam de fato esse indivíduo como uma pessoa mais triste e, por fim, em contraste com o grupo de controle, no qual o líder apresentou o mesmo discurso na ausência de emoções (neutro).

Para analisar o efeito da manipulação foi utilizada a escala completa de afetividade da POMS. Assim, o primeiro teste (Quadro 4) analisou o efeito da manipulação da afetividade positiva sobre os grupos de interesse através da criação de uma variável baseada na subescala positiva da POMS (relacionada as emoções positivas, como alegria ou ânimo). O segundo teste (Quadro 5) analisou o efeito da manipulação da afetividade negativa agressiva sobre os grupos de interesse através da criação de uma variável baseada na subescala negativa da POMS (relacionada as emoções negativas agressivas, como irritação ou fúria). O terceiro teste (Quadro 6) analisou o efeito da manipulação da afetividade negativa passiva sobre os grupos de interesse através da criação de uma variável baseada na subescala negativa da POMS (relacionada as emoções negativas passivas, como tristeza ou desânimo).

No Quadro 4, os resultados da ANOVA e da comparação de médias pelo teste Tukey HSD indicam que houve diferença significativa entre grupos no grau de afetividade positiva do líder $(\mathrm{F}=31,17, \mathrm{p}<0,05)$ como variável dependente. Além disto, conforme mostra a Figura 2, o grupo que assistiu ao vídeo A, onde o líder buscou expressar emoções positivas (alegria), reportou média significativamente mais alta nessa variável $(\overline{\mathrm{x}}=5,87)$, seguido pelo grupo que assistiu ao vídeo $\mathrm{D} /$ neutro $(\overline{\mathrm{x}}=5,27)$, vídeo $\mathrm{B} /$ afetividade negativa agressiva $(\overline{\mathrm{x}}=5,10)$, e vídeo $C$ / afetividade negativa passiva $(\overline{\mathrm{x}}=4,13)$.

Quadro 4 - Efeito da Manipulação (Afetividade Positiva)

\begin{tabular}{|c|c|c|c|c|c|c|}
\hline \multicolumn{2}{|c|}{ ANOVA } & \multicolumn{5}{|c|}{ Comparação Múltipla (Tukey HSD) } \\
\hline \multirow{2}{*}{ F } & Sigma & \multicolumn{2}{|c|}{ Vídeos } & Diferença entre Grupos & DP & Sigma \\
\hline \multirow{3}{*}{31,17} & \multirow{3}{*}{0,000} & \multirow{2}{*}{ Positivo } & Negativo Agressivo & $0,77^{*}$ & 0,19 & 0,000 \\
\cline { 4 - 7 } & & & Negativo Passivo & $1,74^{*}$ & 0,18 & 0,000 \\
\cline { 3 - 7 } & & Neutro & $0,60^{*}$ & 0,19 & 0,010 \\
\hline
\end{tabular}

Obs: variável dependente - Afetividade Positiva.

* Diferença entre médias significativa para um nível de 0,05.

Fonte: elaborado pelo autor. 
Figura 2 - Comparação (Médias) - Efeito da Manipulação (Positiva)

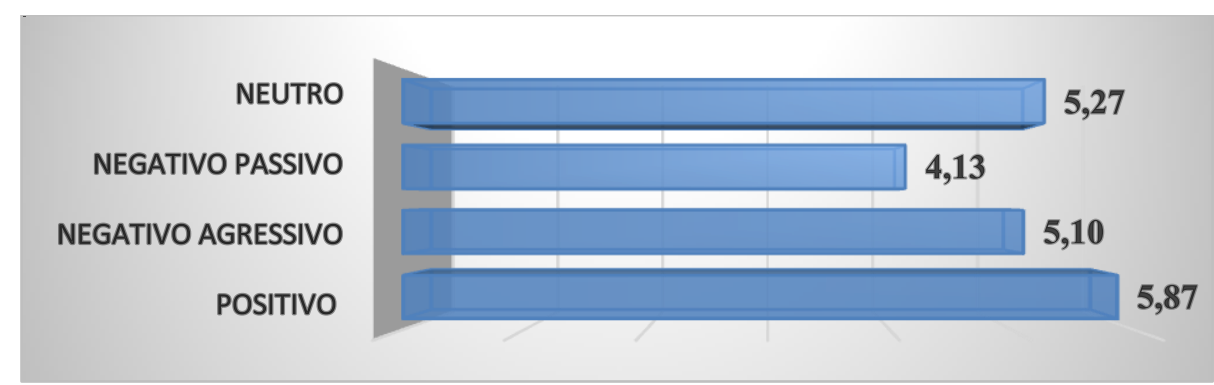

Fonte: elaborado pelo autor.

No Quadro 5, os resultados da ANOVA e da comparação de médias pelo teste Tukey HSD indicam que houve diferença significativa entre grupos no grau de afetividade negativa agressiva do líder $(\mathrm{F}=15,92, \mathrm{p}<0,05)$ como variável dependente. Além disto, conforme mostra a Figura 3, o grupo que assistiu ao vídeo B, onde o líder buscou expressar emoções negativas agressivas (raiva), reportou média significativamente mais alta nessa variável $(\overline{\mathrm{x}}=3,79)$, seguido pelo grupo que assistiu ao vídeo $\mathrm{C} /$ afetividade negativa passiva $(\overline{\mathrm{x}}=3,02)$, vídeo $\mathrm{D}$ / neutro $(\overline{\mathrm{x}}=2,61)$, e vídeo $\mathrm{A} /$ afetividade positiva $(\overline{\mathrm{x}}=2,20)$.

Quadro 5 - Efeito da Manipulação (Afetividade Negativa Agressiva)

\begin{tabular}{|c|c|c|c|c|c|c|}
\hline \multicolumn{2}{|c|}{ ANOVA } & \multicolumn{5}{|c|}{ Comparação Múltipla (Tukey HSD) } \\
\hline $\mathbf{F}$ & Sigma & & lídeos & Diferença entre Grupos & DP & Sigma \\
\hline \multirow{3}{*}{15,92} & \multirow{3}{*}{0,000} & \multirow{3}{*}{$\begin{array}{l}\text { Negativo } \\
\text { Agressivo }\end{array}$} & Positivo & $1,59^{*}$ & 0,24 & 0,000 \\
\hline & & & Negativo Passivo & $0,77^{*}$ & 0,24 & 0,007 \\
\hline & & & Neutro & $1,18^{*}$ & 0,24 & 0,000 \\
\hline
\end{tabular}

Obs: variável dependente - Afetividade Negativa Agressiva.

* Diferença entre médias significativa para um nível de 0,05 .

Fonte: elaborado pelo autor.

Figura 3 - Comparação (Médias) - Efeito da Manipulação (Agressiva)

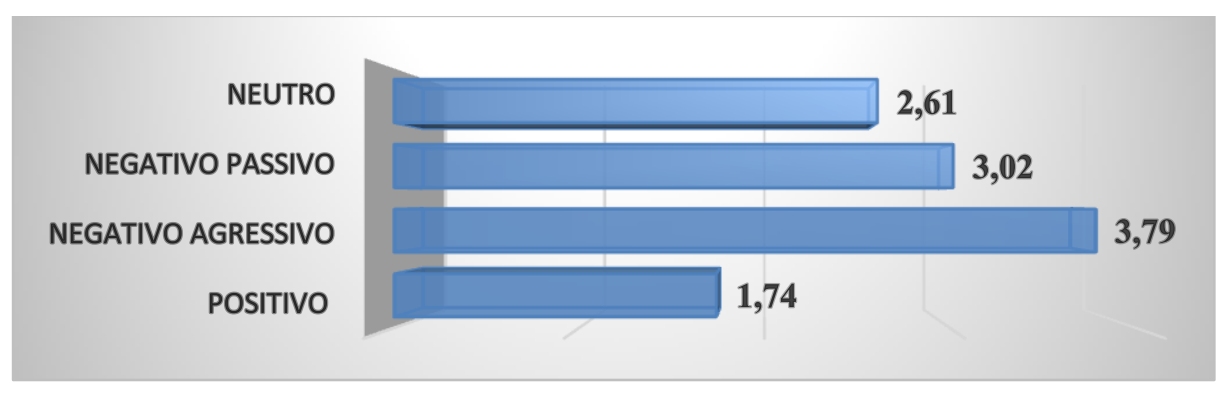

Fonte: elaborado pelo autor. 
No Quadro 6, os resultados da ANOVA e da comparação de médias pelo teste Tukey HSD indicam que houve diferença significativa entre grupos no grau de afetividade negativa passiva do líder $(\mathrm{F}=21,98, \mathrm{p}<0,05)$ como variável dependente. Além disto, conforme mostra a Figura 4, o grupo que assistiu ao vídeo $\mathrm{C}$, onde o líder buscou expressar emoções negativas passivas (tristeza), reportou média significativamente mais alta nessa variável $(\overline{\mathrm{x}}=3,37)$, seguido pelo grupo que assistiu ao vídeo $\mathrm{B} /$ afetividade negativa agressiva $(\overline{\mathrm{x}}=2,23)$, vídeo $\mathrm{D} /$ neutro $(\overline{\mathrm{x}}=2,17)$, e vídeo $\mathrm{A} /$ afetividade positiva $(\overline{\mathrm{x}}=1,74)$.

Quadro 6 - Efeito da Manipulação (Afetividade Negativa Passiva)

\begin{tabular}{|c|c|c|c|c|c|c|}
\hline \multicolumn{2}{|c|}{ ANOVA } & \multicolumn{5}{|c|}{ Comparação Múltipla (Tukey HSD) } \\
\hline $\mathbf{F}$ & Sigma & & Vídeos & Diferença entre Grupos & DP & Sigma \\
\hline \multirow{3}{*}{21,98} & \multirow{3}{*}{0,000} & \multirow{3}{*}{$\begin{array}{l}\text { Negativo } \\
\text { Passivo }\end{array}$} & Positivo & $1,63^{*}$ & 0,21 & 0,000 \\
\hline & & & Negativo Agressivo & $1,14 *$ & 0,21 & 0,000 \\
\hline & & & Neutro & $1,20 *$ & 0,22 & 0,000 \\
\hline
\end{tabular}

Obs: variável dependente - Afetividade Negativa Passiva.

* Diferença entre médias significativa para um nível de 0,05 .

Fonte: elaborado pelo autor.

Figura 4 - Comparação (Médias) - Efeito da Manipulação (Passiva)

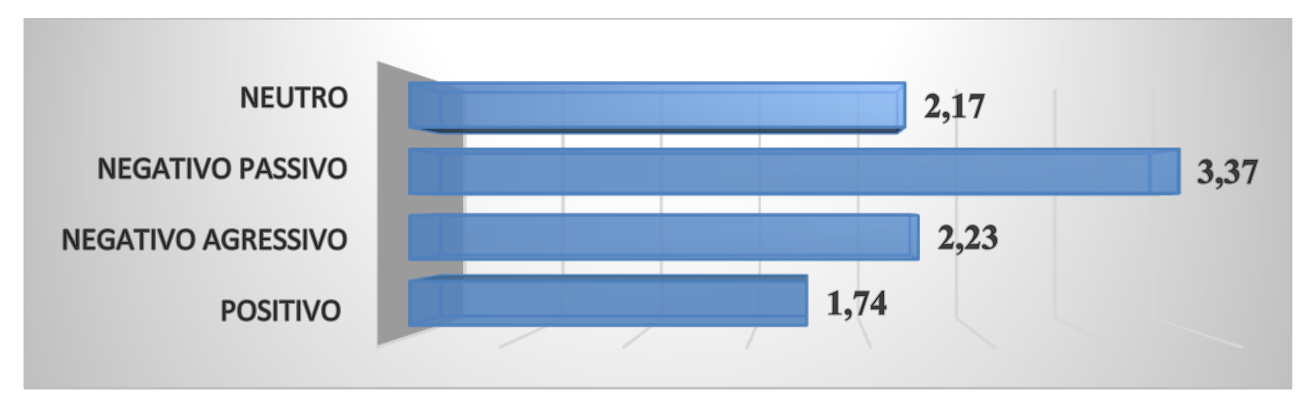

Fonte: elaborado pelo autor.

Assim, pelos resultados expostos nos três quadros anteriores $(4,5$ e 6$)$ e nas três figuras anteriores $(2,3$ e 4$)$ percebe-se que houve diferença significativa entre as variáveis (emoções positivas, negativas agressivas e passivas) analisadas nos quatro grupos demonstrando que o efeito da manipulação das expressões emocionais do líder inautêntico sobre os observadores foi eficaz. 


\section{3}

\section{Construtos e as Expressões Emocionais}

Nesta última etapa, foram feitas as análises para teste das hipóteses da pesquisa (percepção de eficácia, identificação pessoal e julgamento ético do líder) em função da expressão emocional do líder inautêntico. Assim, no Quadro 7, os resultados da ANOVA e da comparação de médias pelo teste Tukey HSD indicam que houve diferença significativa nos julgamentos sobre o líder inautêntico (F = $5,73, \mathrm{p}<0,05)$ quando a análise se ateve à "percepção de eficácia" como variável dependente. Além disto, conforme mostra a Figura 5, o grupo que assistiu ao vídeo A, onde o líder buscou expressar emoções positivas, reportou média significativamente mais alta na percepção da eficácia dos seguidores em relação ao líder inautêntico $(\overline{\mathrm{x}}=2,80)$, seguido pelo grupo que assistiu ao vídeo $\mathrm{C} /$ afetividade negativa passiva $(\overline{\mathrm{x}}=2,26)$, e vídeo $\mathrm{B}$ / afetividade negativa agressiva $(\overline{\mathrm{x}}=2,11)$. Os resultados mostraram também que houve diferença significativa quando a afetividade positiva foi comparada especificamente com as duas emoções negativas, sendo a diferença maior entre a afetividade negativa agressiva $(\overline{\mathrm{x}}=0,68$ e sigma $=0,004)$, seguida da afetividade negativa passiva $(\overline{\mathrm{x}}=0,53 \mathrm{e}$ sigma $=0,031)$. Entretanto, não houve diferença significativa na comparação de médias entre as duas emoções negativas.

Quadro 7 - ANOVA - Percepção de Eficácia

\begin{tabular}{|c|c|c|c|c|c|c|}
\hline \multicolumn{2}{|c|}{ ANOVA } & \multicolumn{5}{|c|}{ Comparação Múltipla (Tukey HSD) } \\
\hline $\mathbf{F}$ & Sigma & & Vídeos & Diferença entre Grupos & DP & Sigma \\
\hline \multirow{6}{*}{5,73} & \multirow{6}{*}{0,004} & \multirow{2}{*}{ Positivo } & Negativo Agressivo & $0,68^{*}$ & 0,21 & 0,004 \\
\hline & & & Negativo Passivo & $0,53^{*}$ & 0,21 & 0,031 \\
\hline & & \multirow{2}{*}{$\begin{array}{l}\text { Negativo } \\
\text { Agressivo }\end{array}$} & Positivo & $-0,68^{*}$ & 0,21 & 0,004 \\
\hline & & & Negativo Passivo & $-0,15$ & 0,21 & 0,751 \\
\hline & & \multirow{2}{*}{$\begin{array}{c}\text { Negativo } \\
\text { Passivo }\end{array}$} & Positivo & $-0,53^{*}$ & 0,21 & 0,031 \\
\hline & & & Negativo Agressivo & 0,15 & 0,21 & 0,751 \\
\hline
\end{tabular}

Obs: variável dependente - Percepção de Eficácia.

* Diferença entre médias significativa para um nível de 0,05.

Fonte: elaborado pelo autor. 
Figura 5 - Comparação (Médias) - Percepção de Eficácia

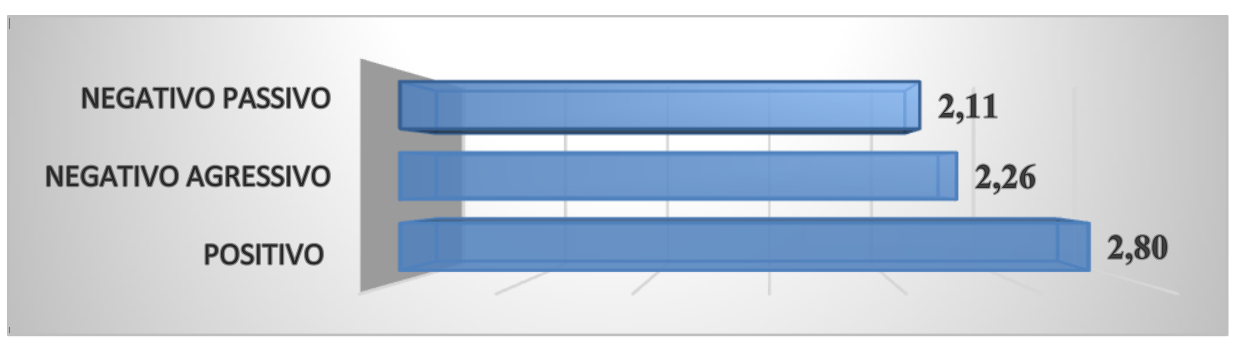

Fonte: elaborado pelo autor.

No Quadro 8, os resultados da ANOVA e da comparação de médias pelo teste Tukey HSD indicam que houve diferença significativa nos julgamentos sobre o líder inautêntico $(\mathrm{F}=5,78, \mathrm{p}<0,05)$ quando a análise se ateve à "identificação pessoal" como variável dependente. Além disto, conforme mostra a Figura 6, o grupo que assistiu ao vídeo A, onde o líder buscou expressar emoções positivas, reportou média significativamente mais alta na identificação pessoal dos seguidores com o líder inautêntico $(\overline{\mathrm{x}}=2,72)$, seguido pelo grupo que assistiu ao vídeo $\mathrm{C}$ / afetividade negativa passiva $(\overline{\mathrm{x}}=2,13)$, e vídeo $\mathrm{B}$ / afetividade negativa agressiva $(\overline{\mathrm{x}}=2,05)$. Os resultados mostraram também que houve diferença significativa quando a afetividade positiva foi comparada especificamente com as duas emoções negativas, sendo a diferença maior entre a afetividade negativa agressiva $(\overline{\mathrm{x}}=0,66$ e sigma $=0,006)$, seguida da afetividade negativa passiva $(\bar{x}=0,58$ e sigma $=0,017)$. Entretanto, não houve diferença significativa na comparação de médias entre as duas emoções negativas.

Quadro 8 - ANOVA - Identificação Pessoal

\begin{tabular}{|c|c|c|c|c|c|c|}
\hline \multicolumn{2}{|c|}{ ANOVA } & \multicolumn{5}{|c|}{ Comparação Múltipla (Tukey HSD) } \\
\hline $\mathbf{F}$ & Sigma & & Vídeos & Diferença entre Grupos & DP & Sigma \\
\hline \multirow{6}{*}{5,78} & \multirow{6}{*}{0,004} & \multirow{2}{*}{ Positivo } & Negativo Agressivo & $0,66^{*}$ & 0,21 & 0,006 \\
\hline & & & Negativo Passivo & $0,58^{*}$ & 0,21 & 0,017 \\
\hline & & \multirow{2}{*}{$\begin{array}{l}\text { Negativo } \\
\text { Agressivo }\end{array}$} & Positivo & $-0,66 *$ & 0,21 & 0,006 \\
\hline & & & Negativo Passivo & $-0,08$ & 0,21 & 0,922 \\
\hline & & \multirow{2}{*}{$\begin{array}{c}\text { Negativo } \\
\text { Passivo }\end{array}$} & Positivo & $-0,58^{*}$ & 0,21 & 0,017 \\
\hline & & & Negativo Agressivo & 0,08 & 0,21 & 0,922 \\
\hline
\end{tabular}

Obs: variável dependente - Identificação Pessoal.

* Diferença entre médias significativa para um nível de 0,05.

Fonte: elaborado pelo autor. 
Figura 6 - Comparação (Médias) - Identificação Pessoal

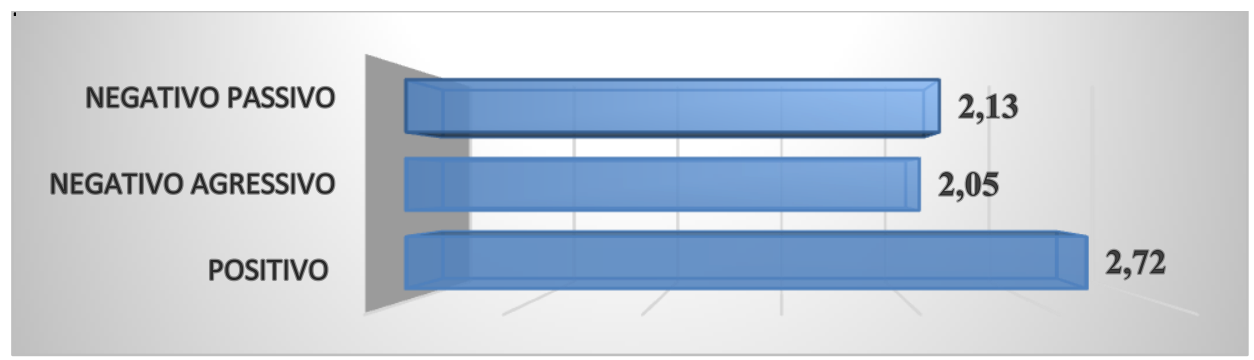

Fonte: elaborado pelo autor.

No Quadro 9, os resultados da ANOVA e da comparação de médias pelo teste Tukey HSD indicam que houve diferença significativa nos julgamentos sobre o líder inautêntico $(\mathrm{F}=3,87, \mathrm{p}<0,05)$ quando a análise se ateve ao "julgamento ético" como variável dependente. Além disto, conforme mostra a Figura 7, o grupo que assistiu ao vídeo A, onde o líder buscou expressar emoções positivas, reportou média significativamente mais alta na avaliação da conduta ética do líder inautêntico $(\overline{\mathrm{x}}=3,53)$, seguido pelo grupo que assistiu ao vídeo $\mathrm{C} /$ afetividade negativa passiva $(\overline{\mathrm{x}}=3,27)$, e vídeo $\mathrm{B} /$ afetividade negativa agressiva $(\overline{\mathrm{x}}=$ $2,74)$. Os resultados mostraram também que houve diferença significativa quando a afetividade positiva fora comparada especificamente com a expressão emocional negativa agressiva $(\overline{\mathrm{x}}=0,79$ e sigma $=0,019)$. Entretanto, não houve diferença significativa na comparação de médias entre a afetividade positiva e a afetividade negativa passiva.

Quadro 9 - ANOVA - Julgamento Ético

\begin{tabular}{|c|c|c|c|c|c|c|}
\hline \multicolumn{2}{|c|}{ ANOVA } & \multicolumn{5}{|c|}{ Comparação Múltipla (Tukey HSD) } \\
\hline $\mathbf{F}$ & Sigma & & Vídeos & Diferença entre Grupos & DP & Sigma \\
\hline \multirow{6}{*}{3,87} & \multirow{6}{*}{0,022} & \multirow{2}{*}{ Positivo } & Negativo Agressivo & $0,79^{*}$ & 0,29 & 0,019 \\
\hline & & & Negativo Passivo & 0,26 & 0,29 & 0,638 \\
\hline & & \multirow{2}{*}{$\begin{array}{l}\text { Negativo } \\
\text { Agressivo }\end{array}$} & Positivo & $-0,79 *$ & 0,29 & 0,019 \\
\hline & & & Negativo Passivo & $-0,53$ & 0,29 & 0,153 \\
\hline & & \multirow{2}{*}{$\begin{array}{c}\text { Negativo } \\
\text { Passivo }\end{array}$} & Positivo & $-0,26$ & 0,29 & 0,638 \\
\hline & & & Negativo Agressivo & 0,53 & 0,29 & 0,153 \\
\hline
\end{tabular}

Obs: variável dependente - Julgamento Ético.

* Diferença entre médias significativa para um nível de 0,05.

Fonte: elaborado pelo autor. 
Figura 7 - Comparação (Médias) - Julgamento Ético

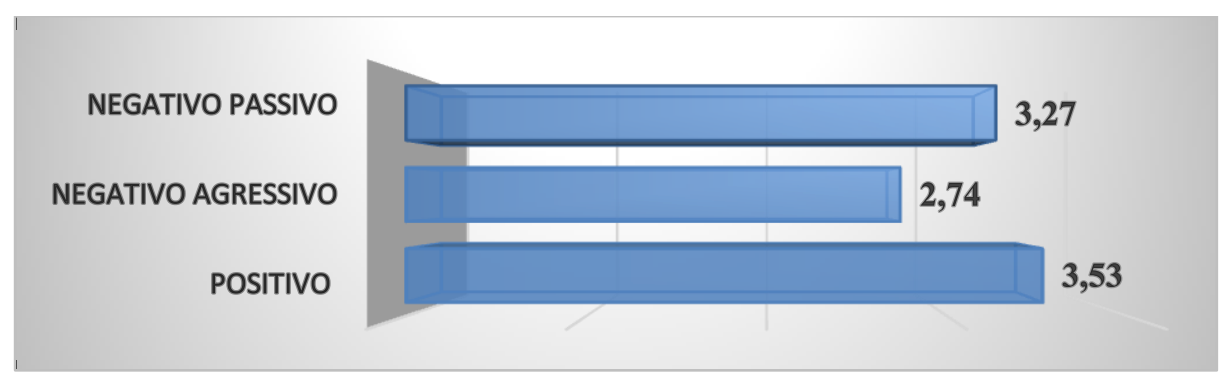

Fonte: elaborado pelo autor.

Pode-se verificar também pela Figura 7 que a afetividade negativa passiva apresentou uma média consideravelmente mais alta em relação a afetividade negativa agressiva na variável do julgamento ético do líder $(\overline{\mathrm{x}}=3,27$ e $\overline{\mathrm{x}}=$ $2,74)$, resultado este que se mostra diferente na comparação de médias das expressões emocionais negativas em relação as variáveis da percepção de eficácia $(\overline{\mathrm{x}}=2,26$ e $\overline{\mathrm{x}}=2,11)$ e identificação pessoal $(\overline{\mathrm{x}}=2,13$ e $\overline{\mathrm{x}}=2,05)$. Assim, foi feito um teste de comparação de médias apenas entre essas emoções negativas. Como pode ser visto pelo Quadro 10, os resultados da ANOVA confirmaram que, apesar de um p-valor marginalmente significante $(F=3,73$ e Sigma =0,055), há uma diferença nos julgamentos do líder que expressa a afetividade negativa passiva em comparação com a afetividade negativa agressiva na variável do julgamento ético do líder. Confirmou-se também, como exposto no Quadro 10 abaixo, a ausência de significância estatística entre essas emoções negativas nas variáveis da percepção de eficácia e identificação pessoal.

Quadro 10 - ANOVA - Emoções Negativas

\begin{tabular}{|c|c|c|c|c|}
\hline \multicolumn{2}{|c|}{ ANOVA } & \multirow{2}{*}{ Construtos } & \multicolumn{2}{c|}{ Médias Individuais } \\
\cline { 5 - 5 } F & Sigma & & $\begin{array}{c}\text { Negativo } \\
\text { Passivo }\end{array}$ & $\begin{array}{c}\text { Negativo } \\
\text { Agressivo }\end{array}$ \\
\hline 0,58 & 0,447 & Percepção de Eficácia & 2,26 & 2,11 \\
\hline 0,16 & 0,690 & Identificação Pessoal & 2,13 & 2,05 \\
\hline 3,73 & $0,055^{*}$ & Julgamento Ético & 3,27 & 2,74 \\
\hline
\end{tabular}

* Diferença entre médias significativa para um nível de 0,05.

Fonte: elaborado pelo autor. 


\section{4 \\ Discussões do Experimento}

De acordo com os resultados da ANOVA e da comparação de médias pelo teste Tukey $H S D$, verificou-se que o líder inautêntico que expressa afetividade positiva (alegria) foi mais bem avaliado em todos os construtos analisados e apresentou significância estatística em todas as comparações de médias que teve com as demais expressões emocionais, exceto na comparação com a afetividade negativa passiva em relação a variável do julgamento ético do líder, em que não foi constatada diferença significativa. Assim, as hipóteses H1a, H1b, H2a, H2b e H2c foram confirmadas e a hipótese H1c não foi confirmada.

O líder que expressa afetividade negativa passiva (tristeza) recebeu as segundas melhores avaliações em todos os construtos analisados em relação a afetividade positiva e a afetividade negativa agressiva, embora tenha apresentado significância estatística apenas na comparação de média com a afetividade negativa agressiva quando a variável foi o julgamento ético do líder. Nas variáveis da percepção da eficácia e identificação pessoal dos seguidores com o líder inautêntico, a comparação de médias entre as duas dimensões negativas não mostrou significância estatística. O líder inautêntico que expressa afetividade negativa agressiva (raiva), por sua vez, recebeu as piores avaliações em todos os construtos investigados. Assim, a hipótese H3c foi confirmada e as hipóteses H1c e H2c não foram confirmadas.

De uma forma geral, constatou-se que as emoções positivas predispuseram as pessoas a construírem julgamentos favoráveis em relação a eficácia e a identificação pessoal com esses líderes quando comparadas com emoções negativas, achados estes que se alinham com uma literatura já sólida sobre a questão investigada, seja em estudos passados (LEWIS, 2000; BONO \& ILIES, 2006; JOHNSON, 2008), como em outros recentes (SADRI et al, 2011; VISSER et al, 2013; JOSEPH et al, 2015). Outro resultado interessante foi a comparação entre as duas dimensões negativas no construto do julgamento ético sobre o líder inautêntico. A expressão emocional negativa agressiva foi pior avaliada em relação a manifestação de expressões negativas passivas. Estes resultados também estão alinhados com outras pesquisas presentes na literatura, como é o caso do estudo de Madera \& Smith (2009). 


\section{5 \\ Conclusão e Considerações Finais}

As emoções afetam profundamente as relações profissionais e podem ser usadas como instrumentos poderosos para beneficiar ambientes de trabalho ou, de forma contrária, manipular pessoas. Assim, o objetivo central do estudo foi testar, por meio de um experimento, se expressões emocionais positivas (alegria), negativas passivas (tristeza/desânimo) e negativas agressivas (enérgico/raiva) manifestadas por um líder tóxico em um discurso inautêntico, poderiam afetar as percepções de eficácia, julgamento ético e a identificação pessoal que os 275 entrevistados formariam desse profissional.

Constatou-se que líderes inautênticos que expressavam emoções alegres foram melhor avaliados do que aqueles tristes e raivosos em relação a sua performance e identificação pessoal. Assim, deduz-se que provavelmente a manipulação feita por um líder inautêntico através de uma postura alegre surtirá mais efeito sobre a percepção de seu desempenho e a identificação pessoal com seus seguidores do que aquele que tenta manipular seus observadores através de uma postura triste e agressiva. Estes resultados são particularmente interessantes de ser analisados, pois conduzem a uma reflexão profunda sobre o cotidiano prático da política e empresariado brasileiro, onde se percebe, de maneira frequente, líderes inautênticos usando-se do carisma e da manipulação de emoções positivas a fim de obterem aceitação, conquistarem apoio ou praticarem atos ilícitos sem serem percebidos.

Quanto a conduta ética julgada pelos observadores em relação ao líder inautêntico, emoções positivas foram melhor avaliadas em relação a emoção negativa agressiva. Entretanto, o mesmo não se pode afirmar sobre a expressão de emoções positivas quando comparadas com aquelas passivas, já que os resultados se mostraram insignificantes do ponto de vista estatístico. Constata-se, então, que o líder tóxico que personifica alguém triste, desanimado, que pode se comportar como vítima de algo ou de alguém, não necessariamente será julgado como um profissional menos ético em relação àquele alegre e que contagia de forma positiva o seu ambiente de trabalho. Talvez, isto seja explicado pelo fato das pessoas, em uma primeira impressão, se sensibilizarem por indivíduos que, a princípio, mostram-se indefesos emocionalmente. 
Outro resultado interessante do ponto de vista do julgamento ético foi a comparação entre as duas dimensões negativas. A expressão emocional negativa agressiva foi pior avaliada em relação a manifestação de um comportamento desanimado e triste por esse líder. Uma das explicações possíveis para este fenômeno seja o fato das pessoas terem dificuldade em perceber de forma imediata os efeitos tóxicos da manipulação emocional sútil desse profissional que se mostra triste, fenômeno este que ocorre de maneira diferente na afetividade negativa agressiva, já que as atitudes de um indivíduo agressivo são bem mais claras e enérgicas, além de ter o poder de fomentar em curto prazo um clima nocivo de tensão e insegurança generalizada entre seus subordinados.

Quanto a limitação deste trabalho, atenta-se para o fato da pesquisa ter sido realizada apenas no ambiente geográfico do Rio de Janeiro e por estudantes de graduação em Administração de Empresas na modalidade de Educação a Distância. Além disto, vale refletir como os participantes reagiriam se o líder inautêntico apresentado nos vídeos fosse uma mulher, um indivíduo mais jovem, apresentasse outro perfil étnico e cultural ou qualquer atributo pessoal diferente daqueles presentes nesse estudo.

Como proposta de pesquisas futuras, sugere-se que o presente trabalho possa ser aplicado em diferentes áreas organizacionais, como Finanças, Gestão de Pessoas, Marketing ou Produção, com estudantes de pós-graduação, na modalidade de ensino presencial, e em cursos que estejam presentes em ambientes empresariais, como Engenharia, Contabilidade, Economia, Comunicação, Psicologia ou outras profissões que colaboram com o desenvolvimento das instituições privadas e públicas. Ademais, outras emoções positivas e negativas não consideradas nesta pesquisa e que tem influenciado consideravelmente as relações profissionais contemporâneas, poderiam ser consideradas e aplicadas em estudos futuros, como seriam os casos de expressões emocionais da ansiedade, medo, empatia ou amor. 


\section{6 \\ Referências bibliográficas}

ANDERSSON, L. M.; BATEMAN, T. S. Cynicism in the Workplace: Some Causes and Effects. Journal of Organizational Behavior, vol. 18, 1997.

ANTONAKIS, J.; ASHAKANASY, N. M.; DASBOROUGH, M. T. Does Leadership need Emotional Intelligence? The Leadership Quarterly, vol. 20, pp. 247-261, 2009.

ANTONAKIS, J. Transformational and Charismatic Leadership. In DAY, D. V. \& ANTONAKIS, J. (Eds.). The Nature of Leadership ( $2^{\text {nd }}$ Edition, pp. 256288). Sage Publications, Thousand Oaks, 2012.

ASHAKANASY, N. M.; HUMPHREY, R. H. A Multi-level View of Leadership and Emotion: Leading with Emotional Labor. In: BRYMAN, A.; COLLINSON, D.; GRINT, K.; JACKSON, B.; UHL-BIEN, M. The Sage Handbook of Leadership, pp. 365-379, 2011.

AVOLIO, B. J.; BASS, B. M. Multifactor Leadership Questionnaire, $3^{\text {a }}$ ed., Manual and Sampler Set. Redwood City, CA: Mind Garden, 2004.

AVOLIO, B. J.; GARDNER, W. L. Authentic Leadership Development: Getting to the Roof of Positive Forms os Leadership. The Leadership Quarterly, vol. 16, pp. 315-338, 2005.

AVOLIO, B. J.; GARDNER, W. L.; WALUMBWA, F. O.; LUTHANS, F.; MAY, D. R. Unlocking the Mask: A Look at the Process by which Authentic Leaders impact Follower Attitudes and Behavior. The Leadership Quarterly, vol. 15, 2004.

BALLINGER, G. A.; SCHOORMAN, F. D.; LEHMAN, D. W. Will you Trust your New Boss? The Role of Affective Reactions to Leadership Succession. The Leadership Quarterly, vol. 20, pp. 219-232, 2009.

BLANCHARD, K.; HODGES, P. The Servant Leader: Transforming your Hearts, Heads, Hands, and Habits. Nashville, TN: Thomas Nelson, 2003.

BONO, J. E.; ILIES, R. Charisma, Positive Emotions and Mood Contagion. The Leadership Quarterly, vol. 17, pp. 317-334, 2006.

BRYMAN, A. Liderança nas Organizações. In: CLEGG, S. R.; HARDY, C.; NORD, W. R. Handbook de Estudos Organizacionais, vol. 3. SP: Atlas, 2004. 
BROWN, M.; TREVIÑO, L.; HARRISON, D. Ethical Leadership: A Social Learning Perspective for Construct Development and Testing. Organizational Behavior and Human Decision Processes, vol. 97, pp. 117-134, 2005.

BURNS, J. M. Transactional and Transforming Leadership. Leadership. New York: Harper \& Row, pp. 100-102, 1978.

CAVAZOTTE, F. S. C. N.; DUARTE, C.; GOBBO, A. Authentic Leader, Safe Work: The Influence of Leadership on Safety Performance. Brazilian Business Review, vol. 10, pp. 95-119, 2013.

CAVAZOTTE, F. S. C. N.; MORENO, V.; BERNARDO, J. E. R. O. Transformational Leaders and Work Performance: The Mediating Roles of Identification and Self-Efficacy. Brazilian Administration Review, 2013.

CHINIARA, M.; BENTEIN, K. Linking Servant Leadership to Individual Performance: Differentiating the Mediating Role of Autonomy, Competence and Relatedness Need Satisfaction. The Leadership Quarterly, 2015.

CIANCI, A. M.; HANNAH, S. T.; ROBERTS, R.; TSAKUMIS, G. The Effects of Authentic Leadership on Follower's Ethical Decision-Making in the Ace of Temptation: An Experimental Study. The Leadership Quarterly, vol. 25, pp. 581-594, 2014.

CIULLA, B. Ethics: The Heart of Leadership ( $2^{\text {nd }}$ Edition), CT: Praeger, 2004. DAY, D. V.; ANTONAKIS, J. Leadership: Past, Present, and Future. In: DAY, D. V.; ANTONAKIS, J. (Eds.). The Nature of Leadership ( $2^{\text {nd }}$ Edition, pp. 3-25). Thousand Oaks: Sage Publications, 2012.

DAY, D. V.; FLEENOR, J. W.; ATWATER, L. E.; STURM, R. E.; MCKEE, R. A. Advances in Leader and Leadership Development: A Review of 25 Years of Research and Theory. The Leadership Quarterly, vol. 25, pp. 63-82, 2014.

DELUGA, R. J. American Presidential Machiavellianism Implications for Charismatic Leadership and Rated Performance. The Leadership Quarterly, vol. $12,2001$.

EINARSEN, S.; AASLAND, M. S.; SKOGSTAD, A. Destructive Leadership: A Definition and Conceptual Model. The Leadership Quarterly, vol. 18, 2007. EKKEKAKIS, P. The Measurement of Affect, Mood, and Emotion: A Guide for Health-Behavioral Research. Cambridge University Press, 2013. FINEMAN, S. A Emoção e o Processo de Organizar. In: CLEGG, S. R.; HARDY, C.; NORD, W. Handbook de Estudos Organizacionais. Vol. 2, SP: Atlas, 2001. 
FINEMAN, S. On Being Positive: Concerns and Counterpoints: Academy of Management Review, vol. 31, pp. 270-291, 2006.

FREITAS, M. E. Organização: Espaço de Negociação. Revista de Administração de Empresas (RAE), São Paulo, vol. 34, nº 5, pp. 13-20, 1994. FRIJDA, N. H. Mood. In: SANDER, D.; SCHERER, K. R. The Oxford Companion to Emotion and the Affective Sciences. New York: Oxford University Press, 2009.

GARDNER, W. L.; COGLISER, C. C.; DAVIS, K. M.; DICKENS, M. P. Authentic Leadership: A Review of the Literature and Research Agenda. The Leadership Quarterly, vol. 22, pp. 1120-1145, 2011.

GARDNER, J. W. The Cry for Leadership. In: WREN, J. T. The Leader's Companion: Insights on Leadership through the Ages. Free Press: NY, 1995.

GEORGE, B. Authentic Leadership: Rediscovering the Secrets to creating lasting Value. San Francisco: Jossey-Bass, 2003.

GOOTY, J.; CONNELLY, S.; GRIFFITH, J.; GUPTA, A. Leadership, Affect and Emotions: A State of the Science Review. The Leadership Quarterly, 2010.

GREENLEAF, R. K. Servant Leadership: A Journey into the Nature of Legitimate Power \& Greatness, 25 ${ }^{\text {th }}$ Anniversary Ed., NY: Paulist Press, 2002.

HANNAH, S. T.; AVOLIO, B. J. Leader Character, Ethos, and Virtue: Individual and Collective Considerations. The Leadership Quarterly, vol. 22, 2011.

HARMS, P. D.; SPAIN, S. M.; HANNAH, S. T. Leader Development and the Dark Side of Personality. The Leadership Quarterly, vol. 22, pp. 495-509, 2011. HARRIS, K. J.; HARVEY, P.; KACMAR, K. M. Abusive Supervisory Reactions to Coworker Relationship Conflict. The Leadership Quarterly, vol. 22, 2011.

HARVEY, P.; HARRIS, K. J.; GILLIS, W. E.; MARTINKO, M. J. Abusive Supervision and the Entitled Employee. The Leadership Quarterly, 2014.

HOOGH, A. H. B.; HARTOG, D. N. D. Ethical and Despotic Leadership, Relationships with Leader's Social Responsibility, Top Management Team Effectiveness and Subordinate's Optimism: A Multi-Method Study, The Leadership Quarterly, vol. 19, pp. 297-311, 2008.

HUGHES, L.; GINNETT, R.; CURPHY, G. Leadership. Ed: Mcgraw-Hill, 2005. IZARD, C. E. Emotion Theory and Research: Highlights, Unanswered Questions, and Emerging Issues. The Annual Review os Psychology, vol. 60, 2009. 
JOHNSON, S. K. I Second that Emotion: Effects of Emotional Contagion and Affect at Work on Leader and Follower Outcomes. The Leadership Quarterly, vol. 19, 2008.

JOSEPH, D. L.; DHANANI, L. Y.; SHEN, W.; MCHUGH, B. C.; MCCORD, M.

A. Is a Happy Leader a Good Leader? A Meta-Analytic Investigation of Leader Trait Affect and Leadership. The Leadership Quarterly, vol. 26, 2015.

KANT, L.; SKOGSTAD, A.; TORSHEIM, T.; EINARSEN, S. Beware the Angry Leader: Trait Anger and Trait Anxiety as Predictors of Petty Tyranny. The Leadership Quarterly, vol. 24, pp. 106-124, 2013.

KELLEY, R. E. In Praise of Followers. Harvard Business Review, 1988.

KELLERMAN, B. Bad Leadership: What It Is, How It Happens, Why It Matters. Harvard Business School Press: Boston, 2004.

KIRKPATRICK, D. S. Social Power and the Coming Corporate Revolution: Why Employees and Customers will be calling the shots. Forbes Journal, 2011.

KLEEF, G. A. V. How Emotions regulate Social Life: The Emotions as Social Information (EASI) Model. Current Directions in Psychological Science, pp. 184-188, vol. 18, 2009.

KONING, F.; KLEEF, G. V. How Leader's Emotional displays Shape Follower's Organizational Citizenship Behavior. The Leadership Quarterly, 2015.

KOTTER, J. P. What Leaders Really Do. Harvard Business Review, 2001.

LEWIS, K. M. When Leaders display Emotion: How Followers respond to Negative Emotional Expression of Male and Female Leaders. Journal of Organizational Behavior, vol. 21, pp. 221-234, 2000.

LUTHANS, F.; AVOLIO, B. J. Authentic Leadership Development. In: CAMERON, K. S.; DUTTON, J. E.; QUINN, R. E. (Eds.). Positive Organizational Scholarship, San Francisco: Berrett-Koehler, 2003.

MADERA, J. M.; SMITH, D. B. The Effects of Leader Negative Emotions on Evaluations of Leadership in a Crisis Situation: The Role of Anger and Sadness. The Leadership Quarterly, vol. 20, pp. 103-114, 2009.

MARKHAM, S. E. The Evolution of Organizations and Leadership from the Ancient World to Modernity: A Multilevel Approach to Organizational Science and Leadership (OSL). The Leadership Quarterly, vol. 23, 2012. 
MARTINKO, M. J.; HARVEY, P.; SIKORA, D.; DOUGLAS, S. C. Perceptions of Abusive Supervision: The Role of Subordinates' Attribution Styles. The Leadership Quarterly, vol. 22, pp. 751-764, 2011.

MATTHIESEN, S. B.; EINARSEN, S. Perpetrators and Targets of Bullying at Work: Role Stress and Individual Differences. Violence and Victims, 2007.

MCCOLL-KENNEDY, J. R.; ANDERSON, R. D. Impact of Leadership Style and Emotions on Subordinate Performance. The Leadership Quarterly, 2002.

MICHIE, S.; GOOTY, J. Values, Emotions, and Authenticity: Will the Real Leader Please Stand Up? The Leadership Quarterly, vol. 16, pp. 441-457, 2005. NASEER, S.; RAJA, U.; SYED, F.; DONIA, M. B. L.; DARR, W. Perils of being Close to a Bad Leader in a Bad Environment: Exploring the Combined Effects of Despotic Leadership, Leader Member Exchange, and Perceived Organizational Politics and Behaviors. The Leadership Quarterly, 2015.

NEAL, M. W.; TANSEY, R. The Dynamics of Effective Corrupt Leadership:

Lessons from Rafik Hariri's Political Career in Lebanon. The Leadership Quarterly, 2010.

NEIDER, L.; SCHRIESHEIM, C. The Authentic Leadership Inventory: Development and Empirical Tests. The Leadership Quarterly, vol. 22, pp. 11461164, 2011.

NEVES, P. Organizational Cynicism: Spillover Effects on SupervisorSubordinate Relationships and Performance. The Leadership Quarterly, 2012.

NEVICKA, B.; HOOGH, A. H. B.; VIANEN, A. E. M. V.; BEERSMA, B.; MCLLWAIN, D. All I Need is a Stage to Shine: Narcissists' Leader Emergence and Performance. The Leadership Quarterly, vol. 22, pp. 910-925, 2011.

MCNAIR, D; LORR, M.; DROPPLEMAN, L. Revised Manual for the Profile of Mood States (POMS). San Diego: Educational and Industrial Testing Services, 1992.

NORTHOUSE, P. G. Leadership - Theory and Practice. Thousand Oaks: Sage Publications, 2013.

OLIVOLA, C. Y.; EUBANKS, D. L.; LOVELACE, J. B. The many (distinctive) Faces os Leadership: Inferring Leadership Domain from Facial Appearance. The Leadership Quarterly, vol. 25, pp. 817-834, 2014. 
O'REILly III, C. A.; DOERR, B.; CALDWELl, D. F.; CHATMAN, J. A. Narcissistic CEOs and Executive Compensation. The Leadership Quarterly, vol. 25, 2014.

PADILLA, A.; HOGAN, R.; KAISER, R. B. The Toxic Triangle: Destructive Leaders, Susceptible Followers, and Conducive Environments. The Leadership Quarterly, vol. 18, pp. 176-194, 2007.

PELLETIER, K. L. Perceptions of and Reactions to Leader Toxicity: Do LeaderFollower Relationships and Identification with Victim Matter? The Leadership Quarterly, vol. 23, pp. 412-424, 2012.

RAJAH, R.; SONG, Z.; ARVEY, R. D. Emotionality and Leadership: Taking Stock of the Past Decade Research. The Leadership Quarterly, vol. 22, pp. 1107-1119, 2011.

RUBIN, R. S.; DIERDORFF, E. C.; BOMMER, W. H.; BALDWIN, T. T. Do Leaders Reap what they Sow? Leader and Employee outcomes of Leader Organizational Cynicism about Change. The Leadership Quarterly, vol. 20, pp. 680-688, 2009.

SADRI, G.; WEBER, T. J.; GENTRY, W. A. Empathic Emotion and Leadership Performance: An Empirical Analysis across 38 Countries. The Leadership Quarterly, vol. 22, pp. 818-830, 2011.

SHAMIR, B.; EILAM, G. "What's your Story?" A Life-Stories Approach to Authentic Leadership Development. The Leadership Quarterly, vol. 16, pp. 395-417, 2005.

SHAW, J. B.; ERICKSON, A.; HARVEY, M. A Method for Measuring Destructive Leadership and Identifying Types of Destructive Leaders in Organizations. The Leadership Quarterly, vol. 22, pp. 575-590, 2011.

SCHYNS, B.; SCHILLING, J. How Bad are the Effects of Bad Leaders? A MetaAnalysis of Destructive Leadership and its Outcomes. The Leadership Quarterly, vol. 24, pp. 138-158, 2013.

SOBRAL, F. J. B. A. Relação Dinâmica entre Confiança, Competitividade e o Processo de Tomada de Decisão Ética em Negociação. RAE Eletrônica, vol. 9, $\mathrm{n}^{\mathrm{o}} 2$, art. $15,2010$.

SOBRAL, F. J. B. A.; GIMBA, R. F. As Prioridades Axiológicas do Líder Inautêntico: Um Estudo sobre Valores e Liderança. Revista de Administração Mackenzie - RAM, São Paulo, vol. 13, nº 3, pp. 96-121, 2012. 
SROUR, R. H. Ética Empresarial: A Gestão da Reputação. Editora Campus/Elsevier, 2a Edição, pp. 60-84, 2003.

STENMARK, C. K.; MUMFORD, M. D. Situational Impacts on Leader Ethical

Decision-Making. The Leadership Quarterly, vol. 22, pp. 942-955, 2011.

STOHS, J.; BRANNICK, T. Irish Managers' Perceptions of Business Ethics'. IBAR - Irish Business and Administrative Research, vol. 17, pp. 83-93, 1996.

SUN, P. Y. T. The Servant Identity: Influences on the Cognition and Behavior of Servant Leaders. The Leadership Quarterly, vol. 24, pp. 544-557, 2013.

TEE, E. Y. J. The Emotional Link: Leadership and the Role of Implicit and Explicit Emotional Contagion Processes across Multiple Organizational Levels. The Leadership Quarterly, vol. 26, pp. 654-670, 2015.

TRICHAS, S.; SCHYNS, B. The Face of Leadership: Perceiving Leaders from Facial Expression. The Leadership Quarterly, vol. 23, pp. 545-566, 2012.

TURANO, L. M. Discurso, Emoções e Autenticidade na Liderança: Um Estudo Experimental. Rio de Janeiro, 2015. Dissertação (Mestrado em Administração) - Departamento de Administração, Pontifícia Universidade Católica do Rio de Janeiro.

VIEIRA, M. M. F.; LACERDA, D. Poder nas Organizações: da Dominação de Poucos à Ação de Muitos. In: PICCININI, V.; ALMEIDA, M.; OLIVEIRA, S. Sociologia e Administração: Relações Sociais nas Organizações. Rio de Janeiro: Elsevier, 2010.

VISSER, V. A.; KNIPPENBERG, D. V.; KLEEF, G. A. V.; WISSE, B. How Leader Displays of Happiness and Sadness influence Follower Performance: Emotional Contagion and Creative Versus Analytical Performance. The Leadership Quarterly, vol. 24, pp. 172-188, 2013.

WALUMBWA, F. O.; AVOLIO, B. J.; GARDNER, W. L.; WERNSING, T. S.; PETERSON, S. J. Authentic Leadership: Development and Validation of a Theory-Based Measure. Journal of Management, vol. 34, pp. 89-126, 2008.

XU, A. J.; LOI, R.; LAM, L. W. The Bad Boss takes it all: How Abusive Supervision and Leader-Member Exchange interact to influence Employee Silence. The Leadership Quarterly, vol. 26, pp. 763-774, 2015. 


\section{APÊNDICE 1 - Discurso do Líder nos Vídeos}

\section{Discurso do CEO}

Prezados colaboradores, bom dia. Eu sou o Roberto Pereira, diretor executivo do Grupo Miller e gostaria de passar algumas informações para vocês sobre a nossa empresa. O Grupo Miller atua no Brasil há sete anos. A nossa empresa conta hoje com aproximadamente quatro mil funcionários, em três estados brasileiros: Rio de Janeiro, São Paulo e Minas Gerais. Desde o início das nossas operações sempre tivemos bons resultados no Brasil. Minas é a nossa operação mais nova e em 2015 uma das nossas metas é consolidar essa posição. No ano passado, mantivemos nossa participação no mercado e até o final de 2016 pretendemos dar continuidade ao plano de expansão dos negócios da Miller no território nacional. Aqui na Miller, os resultados estão acima de tudo. Não importa como o jogo vai ser jogado. Esperamos que quem está no comando, conduza sua equipe com autoridade, e sem melindres. Todas as informações das áreas da empresa são sigilosas. Nós compartilhamos com o público externo apenas aquilo que é estritamente necessário, e o que favorece a imagem da companhia. Nós mantemos o foco nos nossos interesses. Não perdemos tempo com firulas e lero-lero. Queremos com a gente os melhores, aqueles que entram para ganhar. Seja bemvindo ao Grupo Miller. 
APÊNDICE 2 - Manipulação das Emoções do Líder nos Vídeos

Vídeo A - Líder Inautêntico com Emoções Positivas (Alegria)

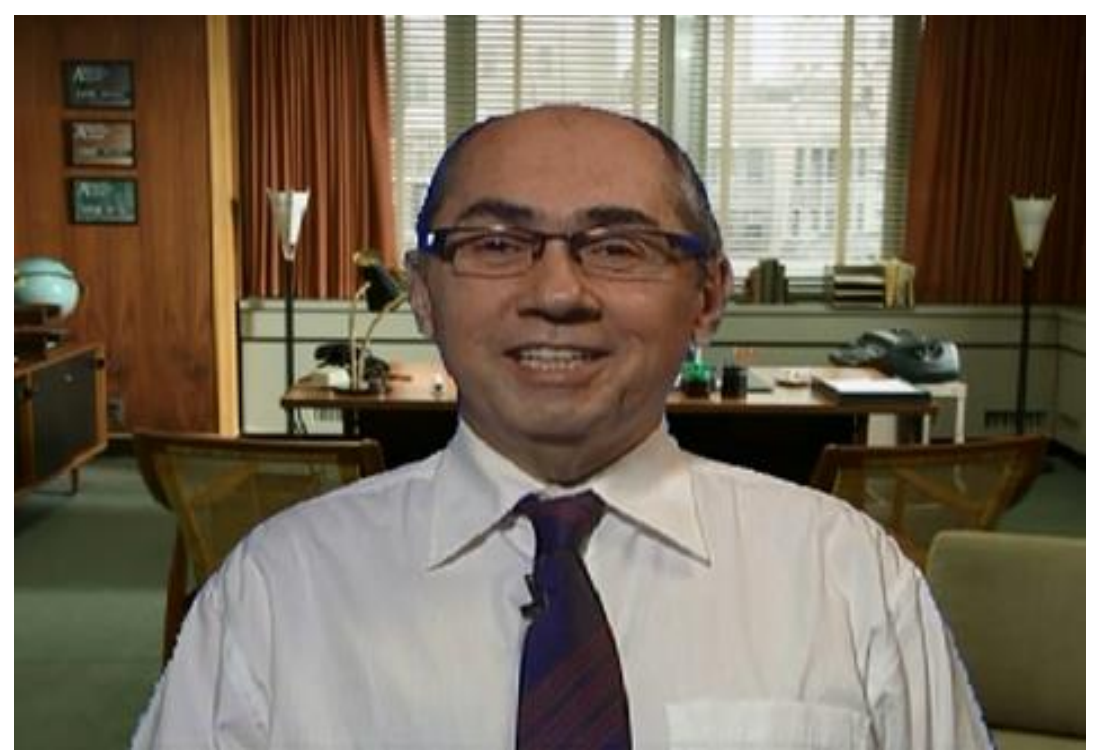

Vídeo B - Líder Inautêntico com Emoções Negativas Agressivas (Raiva)

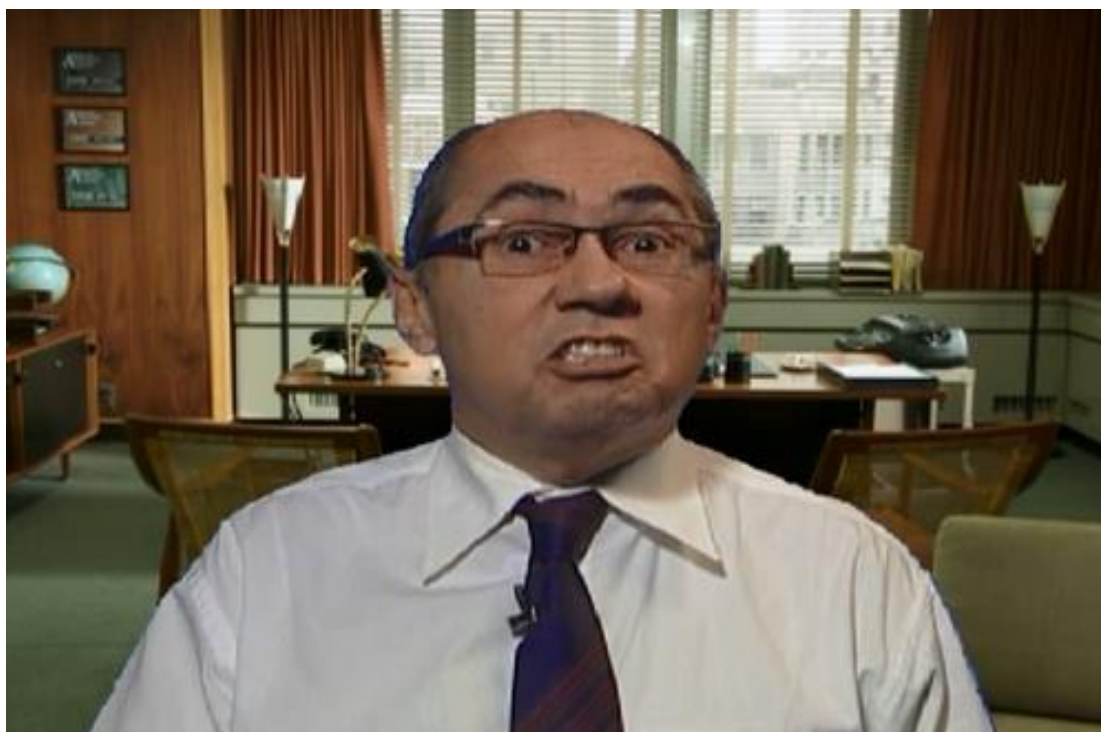


Vídeo C - Líder Inautêntico com Emoções Negativas Passivas (Tristeza)

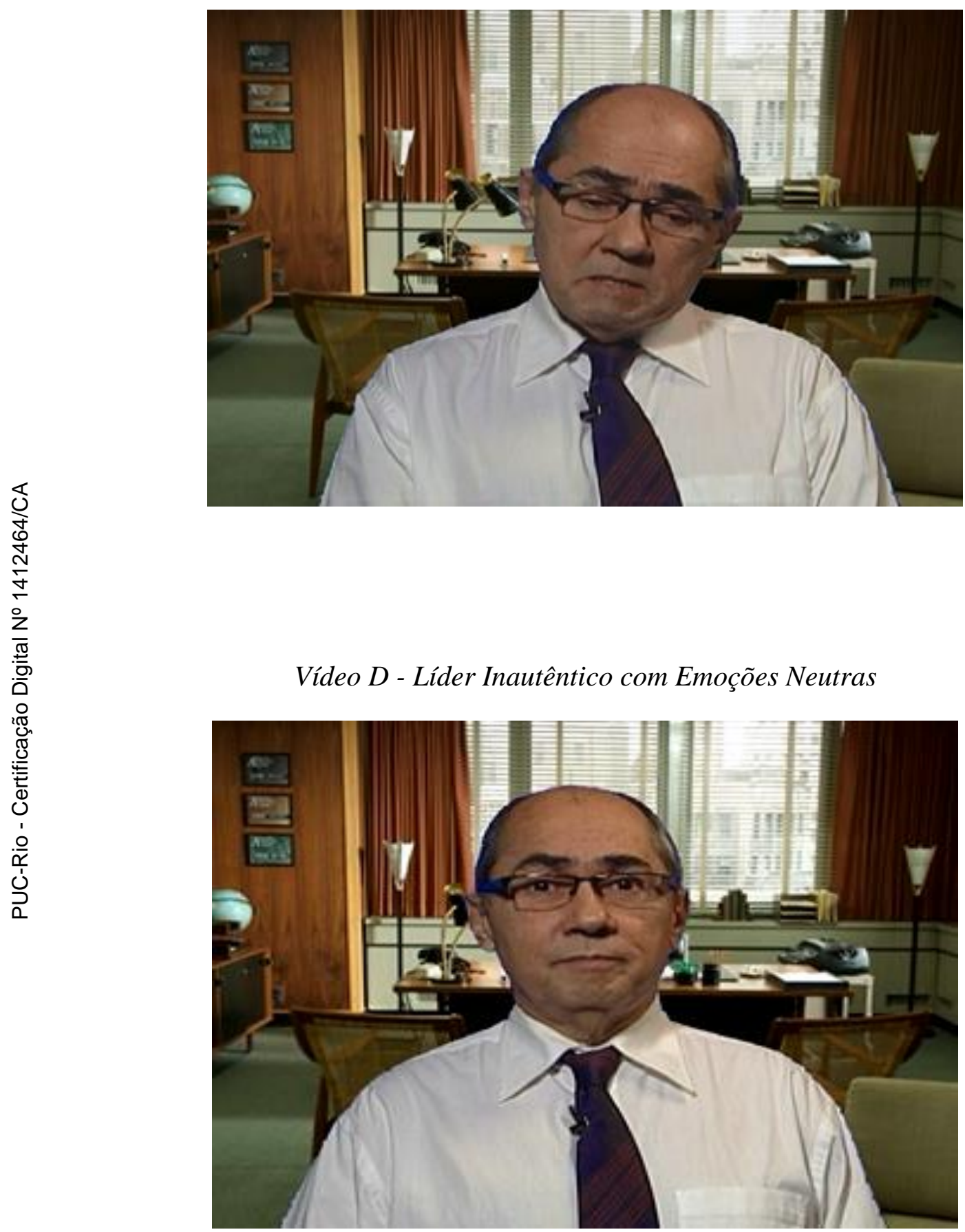




\section{APÊNDICE 3 - Questionário do Experimento}

Prezado (a),

Agradeço a você por acessar a esta pesquisa. Sua participação é voluntária: sinta-se à vontade para interromper esse questionário a qualquer momento.

Você vai assistir a um vídeo, de cerca de um minuto e meio, e responderá em seguida a um questionário. O tempo total de duração da pesquisa é de aproximadamente dez minutos.

Atenção! Antes de iniciar o vídeo, observe as informações abaixo:

1. Esta pesquisa é direcionada a estudantes de Administração que estejam empregados. Caso você não preencha estes requisitos, solicitamos, por gentileza, que não participe.

2. A pesquisa só poderá ser feita por um computador fixo - evite o uso de tablets e smartphones.

3. Você assistirá ao vídeo apenas uma vez. Evite interrupções até o encerramento da pesquisa.

4. A participação na pesquisa só será considerada válida se você completar integralmente o questionário. Portanto, fique atento para não deixar perguntas sem respostas.

5. Esta é uma pesquisa anônima. Por favor, responda às questões da forma mais franca possível. Não é necessário se identificar no questionário.

\section{Muito obrigado!}

Daniel Martins Abelha - abelhadaniel@gmail.com

Mestrado Acadêmico em Administração 
1 - Qual vídeo você assistiu?

Vídeo A ( )

Vídeo B ( )

Vídeo C ( )

Vídeo D ( )

2 - Os itens a seguir se referem ao CEO do vídeo. De acordo com sua percepção, avalie até que ponto estes itens refletem o sentimento dele exposto no vídeo.

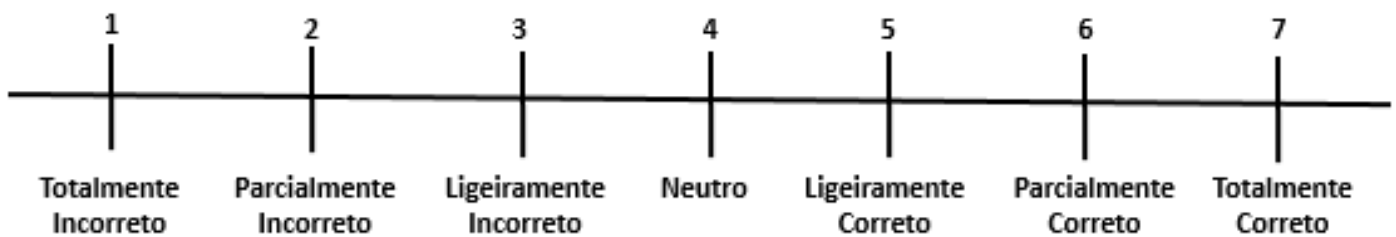

Para você, o líder do vídeo parece...

\begin{tabular}{|l|l|}
\hline & 1. Seguro. \\
\hline & 2. Apreensivo. \\
\hline & 3. Ansioso. \\
\hline & 4. Deprimido. \\
\hline & 5. Triste. \\
\hline & 6. Alegre. \\
\hline & 7. Calmo. \\
\hline & 8. Irritado. \\
\hline & 9. Furioso. \\
\hline & 10. Desanimado. \\
\hline & 11. Animado. \\
\hline & 12. Entusiasmado. \\
\hline & 13. Energizado. \\
\hline & 14. Cansado. \\
\hline & 15. Exausto. \\
\hline
\end{tabular}

3 - Os itens a seguir se referem ao CEO do vídeo. Leias as afirmações abaixo e preencha no quadro ao lado, com base na escala, a opção que melhor descreva sua opinião:

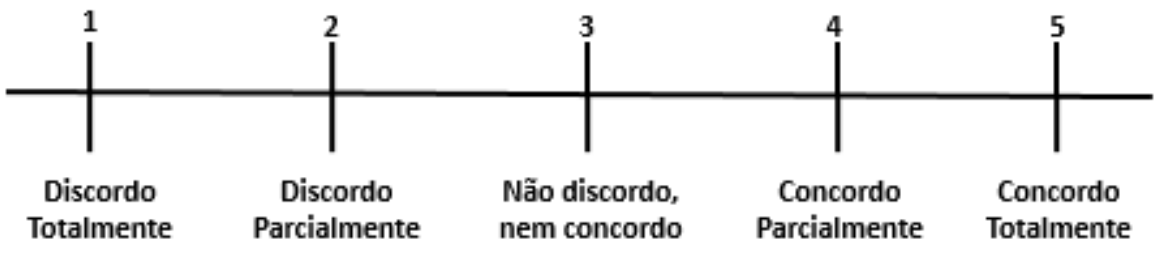




\begin{tabular}{|l|l|}
\hline & 1. Esse CEO corresponde à imagem que eu tenho de um líder. \\
\hline & 2. Esse CEO é um bom líder. \\
\hline & 3. Eu me identifico com esse CEO. \\
\hline 4. Eu gostaria de ter esse CEO como líder formal (chefe). \\
\hline 5. Eu me dedicaria mais e aumentaria minha produtividade com um líder como esse. \\
\hline 6. Eu acredito que esse líder teria um alto desempenho na área em que trabalho. \\
\hline
\end{tabular}

4 - Os itens a seguir se referem ao CEO do vídeo. De acordo com sua percepção, avalie com que frequência cada afirmação abaixo está relacionada ao estilo de liderança dele.

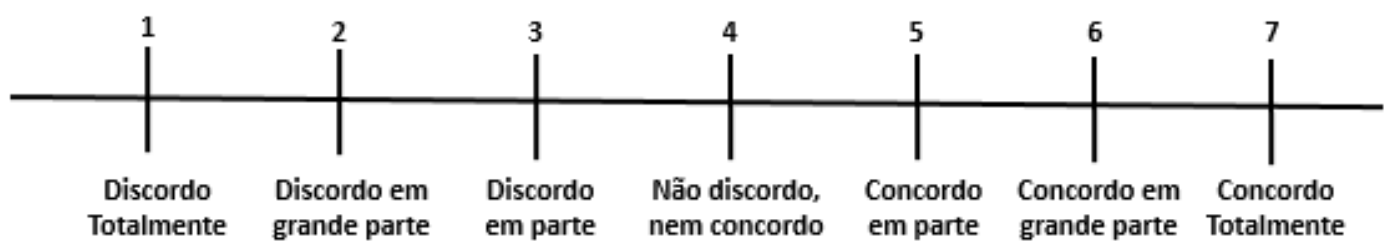

Para você, o líder do vídeo:

1. Conduz sua vida pessoal de maneira ética.

2. Define sucesso não apenas pelos resultados, mas também pela maneira como são alcançados.

3. Escuta o que seus funcionários têm a dizer.

4. Repreende os funcionários que violam padrões éticos.

5. Toma decisões justas e equilibradas.

6. É confiável.

7. Conversa sobre valores ou ética no trabalho com seus funcionários.

8. Dá o exemplo de como fazer as coisas de maneira correta sob o ponto de vista ético.

9. Tem sempre em mente o que é melhor para seus funcionários.

10. Quando toma decisões, se pergunta: "Qual a coisa certa a se fazer?"

5 - Os itens a seguir se referem ao CEO do vídeo. De acordo com sua percepção, avalie com que frequência cada afirmação abaixo está relacionada ao comportamento profissional dele.

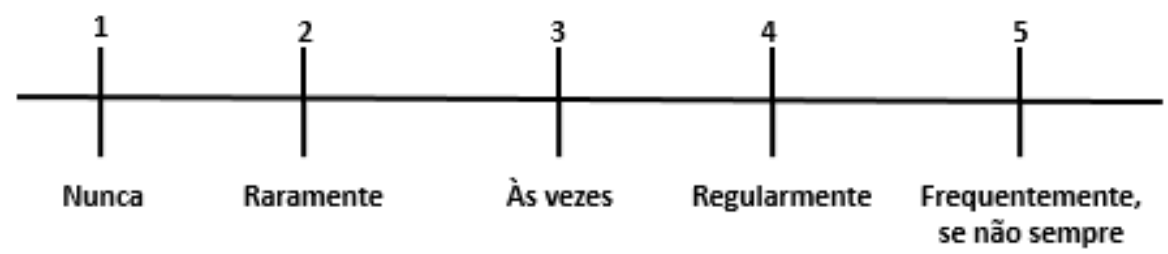

Para você, o líder do vídeo:

\begin{tabular}{|l|l|}
\hline & 1. Diz exatamente o que pensa. \\
\hline & 2. Age de forma coerente com os princípios que defende. \\
\hline 3. Escuta cuidadosamente diferentes pontos de vista antes de chegar a uma conclusão. \\
\hline 4. Sabe quando é o momento de reavaliar sua posição. \\
\hline
\end{tabular}


6 - A seguir, são apresentadas algumas situações do dia a dia no trabalho. Após sua leitura, indique, conforme a escala abaixo, como você avalia os comportamentos adotados.

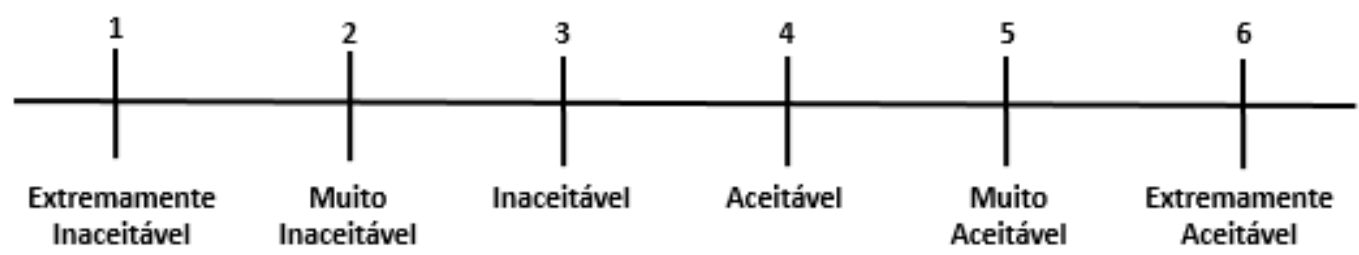

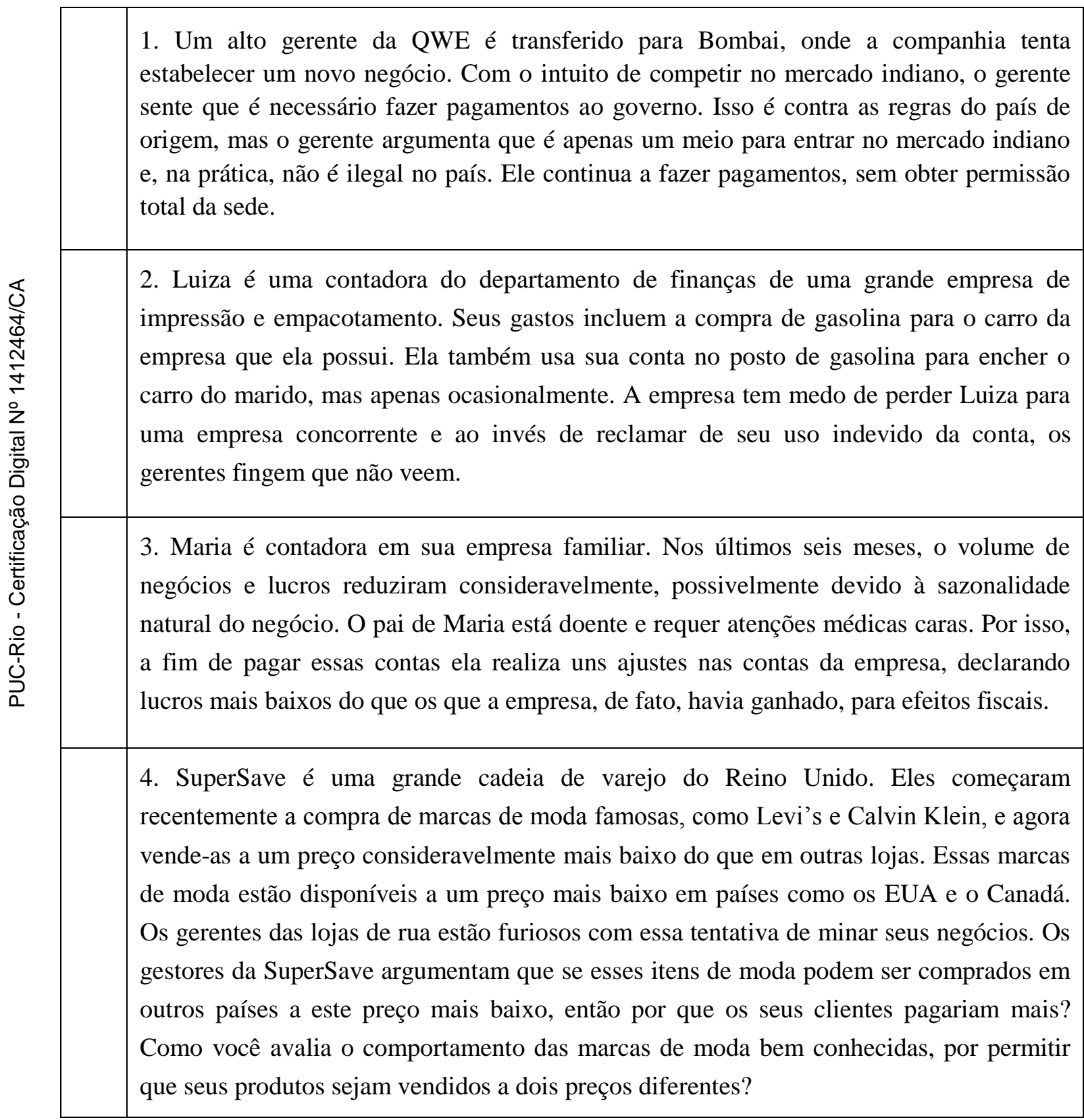




\begin{tabular}{|l|l|}
\hline $\begin{array}{l}\text { 5. Um empregado da Phone Co. não está vendendo tantos celulares quanto seus } \\
\text { superiores gostariam. Foi dito a ele que se não atingir a sua quota, os superiores poderiam } \\
\text { reconsiderar a sua posição na empresa. No esforço para melhorar seus resultados, o } \\
\text { empregado leva muitos clientes a acreditar que, se comprar o produto da empresa, ele terá } \\
\text { a opção de descontos em novos modelos no futuro. A partir de então, as vendas } \\
\text { aumentaram drasticamente e seus supervisores ficaram muito satisfeitos com este } \\
\text { aumento. Contudo, eles não têm conhecimento das ofertas de desconto propostas pelo } \\
\text { empregado. }\end{array}$ \\
\hline $\begin{array}{l}\text { 6. Um funcionário na TXL Co. é responsável pelo pagamento dos credores. Ultimamente, } \\
\text { alguns dos fornecedores têm se tornados cada vez mais impacientes com pagamentos em } \\
\text { atraso e se recusaram a permanecer com os negócios com a TXL Ltd. se isso continuasse. } \\
\text { Uma determinada empresa fornecedora está tendo dificuldades financeiras e estes } \\
\text { pagamentos atrasados estão causando vários problemas. O supervisor do empregado falou } \\
\text { a ele/ela para esperar receber um aviso final antes de pagar quaisquer credores, com } \\
\text { propósitos de fluxo de caixa. }\end{array}$ \\
\hline$\frac{5}{\frac{\delta}{5}}$
\end{tabular}

\section{Questões Demográficas}

1) Sexo: Feminino ( ) Masculino ( )

2) Idade:

3) Período:

4) Tempo de Experiência Profissional:

5) Coeficiente de Rendimento (CR):

Sua participação foi de grande importância para a pesquisa.

Muito Obrigado! 